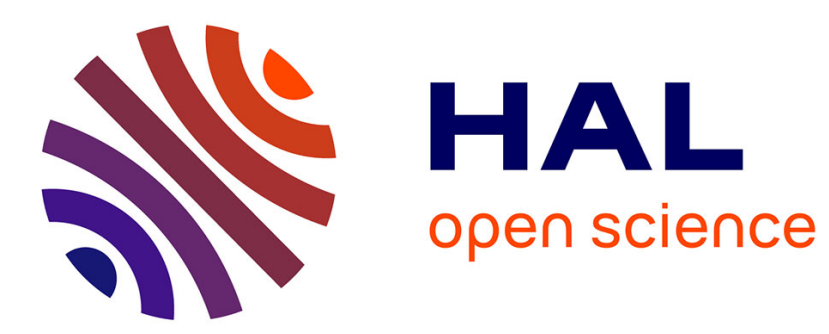

\title{
The scope of traditional and geometric morphometrics for inferences of diet in carnivorous fossil mammals
}

\author{
Sergio Daniel Tarquini, M. Amelia Chemisquy, S. Ladevèze, Francisco J.
} Prevosti

\section{- To cite this version:}

Sergio Daniel Tarquini, M. Amelia Chemisquy, S. Ladevèze, Francisco J. Prevosti. The scope of traditional and geometric morphometrics for inferences of diet in carnivorous fossil mammals. AMEGHINIANA, 2019, 56 (4), pp.307-318. 10.5710/AMGH.24.07.2019.3255 . hal-03099652

\section{HAL Id: hal-03099652 https://hal.science/hal-03099652}

Submitted on 6 Jan 2021

HAL is a multi-disciplinary open access archive for the deposit and dissemination of scientific research documents, whether they are published or not. The documents may come from teaching and research institutions in France or abroad, or from public or private research centers.
L'archive ouverte pluridisciplinaire HAL, est destinée au dépôt et à la diffusion de documents scientifiques de niveau recherche, publiés ou non, émanant des établissements d'enseignement et de recherche français ou étrangers, des laboratoires publics ou privés. 


\section{AMEGHINIIANA}

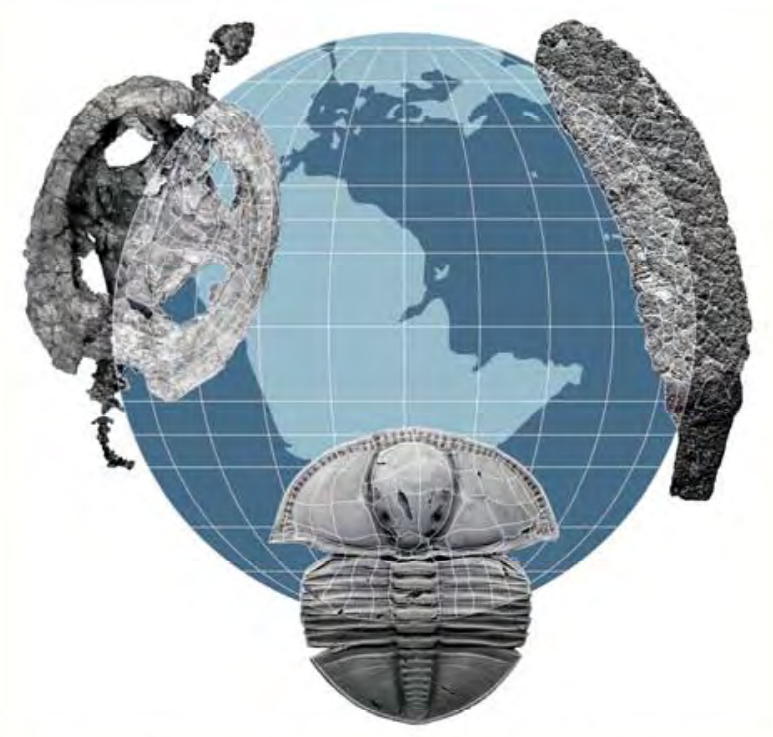

contained in this volume are to be published in future issues of the journal.

Please be aware that during the production process errors may be discovered which could affect the content.

All legal disclaimers that apply to the journal pertain.

Submitted: March $25^{\text {th }}, 2019$ - Accepted: July $24^{\text {th }}, 2019-$ Published online: July $27^{\text {th }}, 2019$

To link and cite this article:

doi: 10.5710/AMGH.24.07.2019.3255 
1 THE SCOPE OF TRADITIONAL AND GEOMETRIC MORPHOMETRICS

2 FOR INFERENCES OF DIET IN CARNIVOROUS FOSSIL MAMMALS

3 SERGIO D. TARQUINI ${ }^{1 *}$, M. AMELIA CHEMISQUY ${ }^{1,2}$, SANDRINE LADEVÈZE

$4{ }^{3}$, AND FRANCISCO J. PREVOSTI ${ }^{1,2}$

5 1- Centro Regional de Investigaciones Científicas y Transferencia Tecnológica de La

6 Rioja (CRILAR - Provincia de La Rioja, UNLaR, SEGEMAR, UNCa, CONICET).

7 Entre Ríos y Mendoza s/n (5301), Anillaco, Argentina. starquini92@gmail.com;

8 amelych80@gmail.com; protocyon@hotmail.com

9 2- Departamento de Ciencias Exactas, Físicas y Naturales, Universidad Nacional de la

10 Rioja (UNLaR). Av. Luis M. de la Fuente s/n (5300), La Rioja, Argentina.

11 3- Centre de Recherche en Paléontologie - Paris (CR2P - CNRS, MNHN, Sorbonne

12 Université). 8 rue Buffon CP38 (75005), Paris, France. sandrine.ladeveze@mnhn.fr

31 pages (text+references); 2 figures; 4 tables; 4 supplementary online information

Proposed header: TARQUINI ET AL.: MORPHOMETRIC METHODS TO INFER

DIET

19

20

* Corresponding author: SERGIO D. TARQUINI 
21 ABSTRACT. Molar morphology is one of the most used proxies for paleoecological inferences in mammals. Since the 19th century, several authors associated dental morphological traits with the diet of an animal by means of qualitative and descriptive analyses. More recently, different studies of tooth function have associated various quantitative traits of tooth shape (i.e., morphometric ratios or angles) with the different items consumed by the animal. However, because different inferences of diet for the same species can be found in the literature, it is crucial to study the power of different proxies. In this work, we compared the utility of classic morphometric indices (RGA, $\mathrm{AI}$ and angle $\alpha$ ) and three-dimensional landmarks configuration to infer diet. Based on a previously published dataset from our working group, we calculated the classic morphometric indices and performed three classification methods: linear discriminant analysis, quadratic discriminant analysis, and weighted random forest. Our results demonstrate that when using the geometric morphometrics approach, the diet of species is better reclassified than when using morphometric indices. Furthermore, intraspecific variation appears fundamental when making paleoecological inferences. In inferring ecological characteristics of extinct animals, studying morphological variation in extant organisms is a safeguard to prevent misinterpretations when reconstructing past ecologies.

KEYWORDS. Diet classification. Carnivora. Morphometric indices. Weighted random forest.

\section{RESUMEN. ALCANCE DE LA MORFOMETRÍA TRADICIONAL Y}

\section{GEOMÉTRICA A LA HORA DE INFERIR LA DIETA EN LOS MAMÍFEROS} FÓSILES CARNÍVOROS. La morfología del molar es uno de los proxies más utilizados para las inferencias paleoecológicas en los mamíferos. Desde el siglo XIX, 
varios autores asociaron algunos rasgos morfológicos dentales con la dieta del animal mediante análisis cualitativos y descriptivos. Más tarde, a partir del siglo pasado, diferentes estudios sobre la función dental han asociado varios rasgos cuantitativos de la forma del diente (es decir, proporciones o ángulos morfométricos) con el porcentaje de carne de vertebrados que consume el animal. Sin embargo, debido a que en la literatura se pueden encontrar diferentes inferencias de la dieta para la misma especie, es crucial llevar a cabo estudios que comparen la precisión de diferentes proxies. En este trabajo, comparamos la utilidad de los índices morfométricos clásicos (RGA, AI y ángulo $\alpha$ ) y la configuración de landmarks tridimensionales con respecto a las inferencias de la dieta.

Sobre la base de un conjunto de datos previamente publicado por nuestro grupo de trabajo, calculamos los índices morfométricos clásicos y realizamos tres métodos de clasificación: análisis discriminante lineal, análisis discriminante cuadrático y análisis de bosques aleatorios ponderados. Nuestros resultados demuestran que al usar la configuración de landmarks, la dieta de las especies se reclasifica mejor que cuando se usan índices morfométricos. Además, considerar la variación intraespecífica al hacer inferencias paleoecológicas parece fundamental. Teniendo el propósito de inferir características ecológicas en animales extintos, la consideración de la variación morfológica en los organismos actuales es una garantía para evitar cualquier interpretación errónea en las reconstrucciones de ecologías pasadas.

PALABRAS CLAVES. Clasificación de la dieta. Carnivora. Índices morfométricos. Bosques aleatorios ponderados. 
THE analysis of diets is an important component of ecological and paleoecological studies (Price et al., 2012; Kissling et al., 2014; Davis and Pineda Munoz, 2016; Croft et al., 2018a). Many proxies have been used to determine the diet of mammalian species, including direct observations of feeding behavior, stomach and fecal contents, dental microwear and mesowear, isotope analysis of nitrogen and carbon, and craniodental morphology, among others (see review in Davis and Pineda Munoz, 2016). Although often considered to represent the same parameter, these different proxies offer different evidences of the items consumed, have different scopes (i.e., extant and/or fossil species), and are constrained by different methodological aspects (i.e., cost, difficulty and time of study, availability of data) (Evans, 2013; Davis and Pineda Munoz, 2016). In particular, the study of molar morphology combines low cost and low methodological difficulty, thus making it one of the most widely used proxies in paleoecological studies of mammals (e.g., Marshall, 1978; Goin et al., 1992; Van Valkenburgh et al., 2004; Vizcaíno et al., 2006; Prevosti et al., 2013; Croft et al., 2018b; Harper et al., 2018).

The versatility of tribosphenic molars has been shown to be a key innovation in the evolution of mammals, increasing the taxonomic diversity and ecological disparity of this group throughout their evolutionary history (Woodburne et al., 2003; Luo, 2007). Molars are also usually the sole identifiable remains of an extinct mammal, and therefore have been intensively used for taxonomic classifications in addition to dietary reconstructions (e.g., Marshall, 1978; Ungar, 2010; Goin and de los Reyes, 2011). Since the 19th century, several authors have associated certain dental morphological traits with dietary habits by means of qualitative and descriptive analyses (e.g., Lund, 1839; Ryder, 1878; Cope, 1879; Butler, 1946; Marshall, 1978; Reig et al., 1987; Berta, 1989). More recently, different studies of tooth function have correlated several quantitative 
traits of tooth shape (i.e., morphometric ratios or angles) with the different items consumed by the animal. These quantitative tools continue to be used today, and while some have used isolated indices (e.g., Crusafont-Pairó and Truyols-Santonja, 1956; Goin et al., 1992; Strait, 1993a, b; Evans et al., 2005; Vizcaíno et al., 2006; Prevosti et al., 2013), others have used several indices to define a morphospace (e.g., Kay, 1975; Van Valkenburgh, 1989; Popowics, 2003; Wesley-Hunt, 2005; Friscia et al., 2007; Asahara et al., 2016; Croft et al., 2018b). Moreover, with the development of new technologies, new dental shape descriptors have been developed to study molar morphology (Evans, 2013). On the one hand, some authors have defined metrics to reflect occlusal surface topography, such as the Dirichlet normal energy, relief index, and orientation patch count (Zuccotti et al., 1998; Ungar and M'Kirera, 2003; Evans et al., 2007; Boyer, 2008; Bunn et al., 2011; Smits and Evans, 2012). On the other hand, other approaches to study tooth morphology have arisen with the development of geometric morphometric techniques, where shape is captured through the use of landmark coordinates (either two- or three-dimensional) and analyzed as a whole, taking into account several shape changes instead of a few measurements (Vizcaíno et al., 2016). For example, some authors have digitized the molars with the aim of assessing the relationships between molar shape and diet: elliptic Fourier analysis has been applied in rodents (Gómez Cano et al., 2013); 2D geometric morphometrics has been used in rodents (Caumul and Polly, 2005), primates (White, 2009), rhinos (Piras et al., 2010), and in didelphid marsupials (Chemisquy et al., 2015; Magnus and Cáceres, 2017); and 3D geometric morphometrics has been used in primates (Cooke, 2011;

Singleton et al., 2011) and in carnivorous species (Tarquini et al., 2018).

The strong form-function relationship of the dentition of living mammals has allowed paleontologists to make inferences of diet in fossil species (e.g., Van 
116 Valkenburgh, 1989; Goin et al., 1992; Prevosti et al., 2013; Zimicz, 2014a; Croft et al., 117 2018b). Within a historical framework, diet reconstructions are crucial for constructing 118 trophic webs, examining evolutionary changes in lineages, and inferring ancient 119 climates and habitats (Pascual and Jaureguizar, 1990; Van Valkenburgh et al., 2004; 120 Dalerum and Angerbjörn, 2005; Prevosti et al., 2013; Echarri et al., 2017). However, in 121 a recent study, we demonstrated the need to take certain precautions before making inferences, because the morphology of the molar not only correlates with diet but also is influenced by the phylogenetic position of each taxa (Tarquini et al., 2018). In any case, the use of different techniques to analyze molar morphology generates the following question: are all methodologies utilized to quantify dental morphology equally reliable? Usually, inferences of diet in South American predatory mammals are tackled with traditional morphometric analyses, using measurements from the lower molars such as the relative grinding area index or the angle of the paracristid to the tooth row (see Materials and Methods for further details; e.g., Van Valkenburgh, 1991; Goin et al., 1992; Zimicz, 2014b; Prevosti and Forasiepi, 2018). However, morphometric ratios or angles only represent some aspects of the shape, and the geometric and spatial relationships among the measurements are not considered (Bookstein, 1991; Rohlf and Marcus, 1993; Adams et al., 2004; Zelditch et al., 2004; Slice, 2007; Mitteroecker and Gunz, 2009). In other words, shape can be better approximated by landmark coordinates than by linear measurements, as has been demonstrated in numerous different test cases (e.g., Fabre et al., 2014; Schmieder et al., 2015; Lallensack et al., 2016). Subsequently, new approaches using 2D geometric morphometrics have been used to study the mandibles of South American predators (Meloro et al., 2008; Prevosti et al., 2012a; Echarri et al., 2017). However, it is important to note that some problems have arisen with the use of $2 \mathrm{D}$ techniques for studying three-dimensional structures, such as the 
141 photographic distortion and the difficulty to capture shape variation as a whole (Álvarez and Perez, 2013; Collins and Gazley, 2017). This led us to hypothesize that 3D geometric morphometrics may turn out to be a more powerful predictive tool than other previously used techniques based on linear measurements, as it represents different aspects of the molar at the same time.

\section{MATERIALS AND METHODS}

\section{Samples and landmarks}

The results of this study are based on the dataset of Tarquini et al. (2018), which includes digitalizations of the first lower molar (m1) of 213 specimens corresponding to 67 extant species of Carnivora, and the fourth lower molars (m4) of 14 specimens corresponding to 4 extant species of Marsupialia, including both Didelphimorphia and Dasyuromorphia (Supplementary Online Information 1). The carnivoran $\mathrm{m} 1$ and carnivorous marsupial $\mathrm{m} 4$ are considered to be functionally analogous teeth following Tarquini et al. (2018). The specimens belonging to the insectivore category from the parent dataset were excluded due to small sample size (only three species: Dasyurus viverrinus, Galerella sanguínea, and Otocyon megalotis). The classification of dietary (ldk 1), carnassial notch in the paracristid (ldk 2), protoconid (ldk 3), metaconid (ldk 4), 
talonid (ldk 5, 8 and 9) (Fig. 1). We also recorded ten semi-landmarks to delimit the base of the crown (Fig. 1). For information regarding landmark and semilandmark treatment, see Tarquini et al. (2018).

\section{Morphometric indices}

In the literature, several indices have been used to analyze the molar morphology of carnivorous mammals. The indices are relationships between measurements, such as the shear ratio (Strait, 1993a, 1993b; Hogue and Ziashakeri, 2010) and the relative lower grinding area (RGA; Van Valkenburgh, 1989; Prevosti et al., 2013). RGA is measured as the square root of the area of the $\mathrm{m} 1$ talonid divided by the relative blade length (BL). The area was estimated as the product of maximum width (WT) and length (LT) of the talonid of $\mathrm{m} 1$, and the BL was estimated as the length of the $\mathrm{m} 1$ trigonid. We use the index as defined by Prevosti et al. (2013), modified from Valkenburgh (1989), which has two advantages: first, it can be applied in fossils that only have the carnassial preserved; and second, the RGA value can be compared in both Carnivora and Metatheria. Other indices include morphometric angles, such as those that describe the relationship between the paracristid and the mesiodistal axis (lower angle, AI; Goin et al., 1992) or the relationship between the height of the protoconid and the length of the talonid (angle $\alpha$; Crusafont-Pairó and Truyols-Santonja, 1953, 1956; Wesley-Hunt, 2005; Meloro and Raia, 2010).

Using the configuration of landmarks mentioned above, we calculated the following morphometric indices with Rhinoceros 3D V5.0 software: angle $\alpha$, AI, and RGA. The angle $\alpha$ was calculated using ldks 3, 8 and 9 . For AI, ldk 1, 3, 8 and 9 were used. RGA was calculated using ldks 5, 8 and 9 and the two semilandmarks that define the maximum width of the talonid (Fig. 1). 

measurement of the blade length (BL', i.e., distance between the paraconid, ldk 1, and the protoconid, $1 \mathrm{dk} 3$ ) and a more accurate measurement of the area of the $\mathrm{m} 1$ talonid (i.e., polygon area (PA) formed by all semilandmarks of talonid) (Fig. 2). However, neither using the $\mathrm{BL}^{\prime}$ nor using the PA led to better discriminating functions; consequently, the detailed results are not reported here.

\section{Statistical analyses}

We used the scores of between-group PCA (bg-PCA) conducted in Tarquini et al. (2018) for the new analyses (see below). The bg-PCA can be understood as a PCA in two steps: first, we made a PCA with the average shape of each dietary category, and then we plotted the entire dataset on these axes (Mitteroecker and Bookstein, 2011; Seetah et al., 2012). We used the axes of bg-PCA as representatives of shape, which brings about two advantages. First, when the axes of the PCA are constructed, the variance of the whole sample is maximized, while in the bg-PCA, the variance of the dietary categories is maximized but without distorting the geometry of the multivariate space (Klingenberg and Monteiro, 2005; Mitteroecker and Bookstein, 2011). Second, fewer axes are obtained in bg-PCA (the number of categories minus one, in this case four) than in PCA, which avoids problems with the quantity of variables when using PC axes in discriminant analyses (Kovarovic et al., 2011) but without discarding any morphological information.

In order to study the behavior of morphometric indices, we performed three analyses. First, we evaluated the covariation between indices to test independence in the case of using them as variables of the same analysis. We performed a Spearman correlation since the Shapiro-Wilk test demonstrated that the indices are not normally 
distributed. The Shapiro-Wilk test, the Spearman correlation and regression analyses were performed using the stats package for the software R 3.5.1 (R Core Team, 2018). Second, we conducted a multivariate regression to quantify how much of the change in the shape (Procrustes coordinates) could be explained by the different indices. Finally, we performed a simple linear regression between the various indices and the axes of the bg-PCA. Following the regressions, a permutation test was performed to evaluate the complete independence between the dependent and independent variables. Regression analysis and the permutation test were performed using the software MorphoJ 1.06b (Klingenberg, 2011).

Although a PCA or bg-PCA would allow us to see the graphical distribution of the diet taking into account the values of the different predictor variables (angle $\alpha, \mathrm{AI}$, RGA, or landmark configuration), it is important to quantify the relative performance of each predictor variable to infer diets. That is the reason why we conducted several linear discriminant analyses (LDA): some with the scores of the bg-PCA (to analyze the scope of geometric morphometrics) and others with the morphometric indices, together and separately (to analyze the scope of traditional morphometrics). Given the known problems of performing a LDA with geometric morphometrics data (Kemsley, 1996; Sheets et al., 2006), and to avoid a bias due to the analysis used, we also carried out two learning methods for classification: quadratic discriminant analyses (QDA) and random forest analyses (RF). The QDA is very similar to the LDA but does not assume identical covariance for each class and produces a quadratic boundary between the classes (Venables and Ripley, 2002; Dixon and Brereton, 2009). The RF is a nonmetric method based on bootstrap resampling techniques of decision trees, which have made it a powerful tool with greater precision than neural networks, classification trees, linear and quadratic DAs, and k-nearest neighbors (Breiman, 2001; Maroco et al., 2011). 
However, the regular RF is constructed to minimize the overall error rate, so it tends to be biased toward the majority class (Chen et al., 2004; Zhu and Pierskalla, 2016). Given that our dataset is unbalanced (i.e., there are six herbivores, 105 hypercarnivores, 34 mesocarnivores, 71 omnivores, and 13 piscivores), we proceeded to perform a weighted random forest (WRF), as proposed by Chen et al. (2004), which avoids the bias towards the most numerous classes. To evaluate the performance of classification methods based on different predictors, we compared the percentage of correct posterior reclassification (PCPR) and the error rate (\% Error) calculated from the confusion matrix. This is obtained in an innate way by the bootstrap resampling in the WRF and from the crossvalidation procedure in both LDA and QDA (Breiman, 2001; Venables and Ripley, 2002; Kovarovic et al., 2011). PCPR was calculated globally and for each category; it is understood as the number of animals correctly reclassified in a dietary category divided by the total of animals belonging to that category. \% Error was calculated for each category as the number of animals wrongly reclassified in a dietary category divided by the total of animals reclassified in that category. Additionally, as mentioned above, molar morphology has a significant phylogenetic signal, so that within each family, the degree of morphological variation is variable (Tarquini et al., 2018). For that reason, we repeated the classification methods only with the species of the Canidae subgroup, which is also a group where morphometric indices are widely used. LDA, QDA and WRF were performed using the MASS and randomForest packages (Liaw and Wiener, 2002; Venables and Ripley, 2002) in R 3.5.1 (R Core Team, 2018).

\section{Intraspecific variation}

When reviewing previous works, we noted that a few authors have considered intraspecific variation, whereas the majority have not. To compare criteria, we analyzed RGA values calculated from unpublished measurements taken by calipers (Prevosti, 
2006) and compared using the average RGA value per species to using RGA values for each specimen separately.

\section{RESULTS}

The morphometric indices showed high and significant correlations: RGA vs. angle $\alpha(\rho=-0.87$, p-value $<0.0001)$, RGA vs. AI $(\rho=0.88$, p-value $<0.0001)$ and AI vs. angle $\alpha(\rho=-0.77, p$-value $<0.0001)$. The regressions against the Procrustes coordinates showed that the indices have a low correlation with shape variation: RGA explained $53.30 \%$ of the change in the shape (p-value $<0.0001$ ), AI explained $37.37 \%$ (p-value < 0.0001) and angle $\alpha$ explained 49.42\% (p-value < 0.0001). By contrast, bgPC1 (the axis that has the highest proportion of shape change in the bg-PCA) explained the shape variation better than any of the morphometric indices (76.59\% percent of variance). Finally, when we analyzed the covariation between the bg-PCs and the morphometric indices, we observed that a large portion of variation explained by bgPC1 could also be explained by the morphometric indices (percentage of covariance greater than 60\%; Tab. 1), whereas there was a low covariation between the morphometric indices and the other axes of bg-PCA (percentage of covariance less than 20\%; Tab. 1).

The three classification methods (LDA, QDA and WRF) returned a similar pattern of global PCPR (Tab. 2). The only differences observed were in the performance of the indices when comparing them to each other. However, in all cases when using the scores of the bg-PCA, the diet of a species was better reclassified than when using morphometric indices. Hereafter, we describe the results of WRF to transmit the idea more clearly, which are shown in Table 2 together with the results of the other two analyses. Using all the axes of the bg-PCA, the WRF correctly reclassified $89.96 \%$ of 
the specimens; using only the first axis, the PCPR was 74.67\% (Tab. 2). On the other hand, none of the analyses using individual morphometric indices exceeded 66 PCPR (Tab. 2). Even using all of the indices together, the PCPR was only $75.98 \%$ (Tab. 2). excellent reclassification (higher PCPR and lower \% Error) in the hypercarnivorous and piscivorous categories, and a good reclassification (higher PCRP and average \% Error) in the mesocarnivorous and omnivorous categories, while it had a bad reclassification (low PCPR and average \% Error) in the herbivorous category (Supplementary Online Information 2). Otherwise, the models with the morphometric indices tended to reclassify the different dietary categories with higher \% Error (regardless of the value of PCPR) than the model with bg-PCs (Supplementary Online Information 2).

Additionally, the indices tend to have a bias to hypercarnivores since it is usually the category with the highest PCPR and the lowest \% Error (Supplementary Online Information 2).

When we subdivided the dataset and scrutinized only the Canidae, the results did not change substantially. The scores of the bg-PCA still better reclassified the diet of species than the morphometric indices (Tab. 3 and Supplementary Online Information 3). The discriminant function obtained with the scores of the bg-PCA had a 92.31 PCPR, while that obtained with the indices the PCRP did not exceed $68 \%$ (Tab. 3 ). Finally, in the intraspecific variation test, we observed that when using the average value of RGA, the separation between dietary categories was clearer than when using all the values of each specimen (Supplementary Online Information 4). Using the average values, under this example, the diets could be classified with a series of logical rules: a taxon can be considered hypercarnivorous when the RGA index is lower than 
3110.45 ; mesocarnivorous when the RGA index range from 0.46 to at least 0.47 ;

312

313

314

315

316

317

318

319

320

321

322

323

324

325

326

327

328

329

330

331

332

333

334

335

omnivorous when the RGA index ranges from 0.60 (perhaps lower) to 0.68 ; and insectivorous when the RGA index is larger than 1 . However, when the index is between 0.48 and 0.59 , the classification is ambiguous, and the taxon may be omnivorous or mesocarnivorous. On the other hand, if intraspecific variation is considered, the superposition zone is much larger. If the value of RGA is lower than 0.40 , the taxon is hypercarnivorous; between 0.40 and 0.42 , it may be hypercarnivorous or mesocarnivorous; between 0.43 and 0.48 , it may be hypercarnivorous, mesocarnivorous or omnivorous; between 0.48 and 0.69 , it may be mesocarnivorous or omnivorous; and larger than 1, it is insectivorous (Supplementary Online Information 4).

\section{DISCUSSION}

Because of the hardness of dental tissues, teeth are the mammalian body parts most likely to be preserved in the fossil record and, consequently, the elements most frequently found and studied (Carlson, 1989; Benton and Harper, 2009; Ungar, 2010). Combined with the importance of the teeth in the acquisition and processing of food, this makes tooth morphology an important source of information for understanding and inferring the ecological habits of fossil species (e.g., Van Valen, 1969; Kay, 1975;

Marshall, 1978; Van Valkenburgh, 1989; Prevosti et al., 2013; Solé and Ladevèze, 2017; Tarquini et al., 2018). Bearing that in mind, there have been different inferences of diet for the same species in the literature, making it necessary to carry out studies that include diverse proxies (e.g., Soibelzon et al., 2014; Pineda-Munoz et al., 2017) or to compare the power of different proxies. Our results indicate that 3D geometric morphometrics is a very powerful tool to study molar morphology and is better than traditional morphometrics when it comes to predicting feeding habits. The discriminant 
function obtained (regardless of the chosen classification method) displays a greater predictive power than that obtained from the indices (Tabs. 2 and 3). Since the PCPR tends to increase when adding explanatory variables, we performed the classification methods with the first bg-PC to compare against isolated indices, and with the first three bg-PCs against the combined indices. All comparisons showed that geometric morphometric data are better for classifying diets than classical morphometric indices (Tabs. 2 and 3). Although the bg-PC1 explained more shape variation than any of the indices, the variation within this first axis could be explained partially using the indices (e.g., specimens at the positive end of bg-PC1 have a molar with the paracristid parallel to the mesiodistal axis and the talonid is reduced or absent; Tarquini et al., 2018).

It is noteworthy that the bg-PCA, based on geometric data, provided a diffused low degree of separation between diet categories, with different degrees of overlap among them. Nevertheless, as we discussed in a previous work (Tarquini et al., 2018), this might be in part related to the intrinsic definition of diets and the disadvantage of the discretization of a continuous variable such as diet into classes, whose chosen limits are questionable (Van Valkenburgh, 1989; Van Valkenburgh and Koepfli, 1993; Prevosti et al., 2012b; Echarri et al., 2017). This is why this problem is not intrinsically related to geometric morphometric, and in studies that include a broad taxonomic sampling (several species across all Carnivora), it appears difficult to choose a unique value of RGA (or equivalent index) to separate each dietary categories (Van Valkenburgh, 1989; Friscia et al., 2007; Zimicz, 2012; Prevosti et al., 2013). Some authors have chosen to use several indices to define morphospaces that better separate the categories (Van Valkenburgh, 1989; Friscia et al., 2007), although these ratios have high correlation values between them (as also calculated here). This is due to the fact that the indices are calculated with anatomical points or landmarks in common. This 
361 issue is easily circumvented with geometric morphometrics because it avoids any overrepresentation of data by working directly with the landmarks coordinates. less inclusive clade, the Canidae (Tab. 3 and Supplementary Online Information 3). Although there are differences in the performance of the indices when comparing them to each other (e.g., RF and LDA indicated that the $\mathrm{AI}$ is the best diet estimator, while QDA indicated that the RGA is the best one), they all agreed that the scores of the bgPCA better reclassified the diet of species. When examining where the differences in the reclassification were, the confusion matrix showed that, whatever the classification method, the morphometric indices principally struggled to discern correctly hypercarnivores form mesocarnivores. Van Valkenburgh (1991) pointed out that although the molars of hypercarnivorous canids (Canis lupus, Cuon alpinus, Lycaon pictus, and Speothos venaticus) are specialized, they do not reach the cat-like extreme condition seen in felids and, to a lesser degree, in hyaenids. For this reason, when we calculated the indices, hypercarnivores and mesocarnivores overlapped and were reclassified erroneously (Tab. 4). This problem was not mentioned by previous authors, since they worked with the average of the indices (see below).

When reviewing previous works, we also noted that another criterion that differs in the methodologies is the use of the average value of the index per species versus the use of the observed variation (i.e., including the value of each specimen separately). In this work, we considered all specimens individually in order to properly account for intraspecific morphological variation. Goin et al. (1992) calculated a series of basic 
statistics (such as mean, variance, standard deviation, etc.) to evaluate intraspecific morphological variation in the molars of didelphids, whereas in the majority of the other works (Van Valkenburgh, 1989; Prevosti et al., 2013), the authors only used the average value, without specifying exactly how many specimens were measured for each species. To compare criteria, we analyzed the indices calculated from the landmarks and others from unpublished measurements taken by calipers (Prevosti, 2006) and discovered that if the maximum and minimum values of each species are considered, the ranges of overlap between the dietary categories used increases (Supplementary Online Information 4). In fact, it is possible that the use of a central tendency statistic minimizes the real overlap that exists between categories. However, this problem persists when there are few specimens per species (which is commonly the case in fossil taxa), since the average value of the specimens examined is not likely to be representative of the actual average value for the species, which in turn is likely to lead to misinterpretations in the ecology of the fossil species analyzed.

\section{CONCLUSION}

This work quantitatively evaluated the power of different proxies to describe the molar morphology of extant carnivore mammals and how it relates to diet. Our results demonstrated that 3D geometric morphometrics is better than traditional morphometrics to predict feeding habits, as using landmarks provides more information than working with isolated measurements or angles of teeth. Moreover, we discussed the importance of considering the intraspecific variation. As the ultimate purpose of these analyses is to infer ecological characteristics in fossils, misinterpretations in the ecology of the fossil specimens can be avoided when the variation of extant organisms is considered. 

allow a better comprehension of the ecology of these animals. Having more precise classifications about different ecological traits of the South American carnivorous mammals would allow us to test extinction hypothesis of some carnivore guilds with greater assurance.

\section{ACKNOWLEDGEMENTS}

We thank D. Flores and P. Teta (MACN-ma) and I. Olivares (MLP-ma) for access to specimens under their care; J. Rajmil, C. Bustamante, W. Bustamante, and M. Mignana for replicas of molars deposited in foreign collections; M. Macchioli Grande for helping with the English version of the manuscript; D. Croft, R. Engelman, A. Friscia, and A.

Otero for providing useful comments that helped improve the manuscript. This is a contribution to projects PICT-2015-0966 and PUE 2016-0125.

\section{REFERENCES}

Adams, D.C., Rohlf, F.J. and Slice, D.E. 2004. Geometric morphometrics: ten years of progress following the 'revolution'. Italian Journal of Zoology 71: 5-16.

Álvarez, A. and Perez, S.I. 2013. Two- versus three-dimensional morphometric approaches in macroevolution: insight from the mandible of Caviomorph Rodents. Evolutionary Biology 40: 150-157.

Asahara, M., Saito, K., Kishida, T., Takahashi, K. and Bessho, K. 2016. Unique pattern of dietary adaptation in the dentition of Carnivora: its advantage and developmental origin. Proceedings of the Royal Society B 283: 20160375.

Benton, M.J. and Harper, D. a. T. 2009. Introduction to paleobiology and the fossil record. Wiley-Blackwell, Chichester, 609 p. 
Berta, A. 1989. Quaternary evolution and biogeography of the large South American Canidae (Mammalia: Carnivora). University of California Publication Geological. Sciences 132: 1-149.

Bookstein, F.L. 1991. Morphometric tools for landmark data: geometry and biology. Cambridge University Press, New York, 357 p.

Boyer, D.M. 2008. Relief index of second mandibular molars is a correlate of diet among prosimian primates and other euarchontan mammals. Journal of Human Evolution 55: 1118-1137.

Breiman, L. 2001. Random Forest. Machine Learning 45: 5-32.

Bunn, J.M., Boyer, D.M., Lipman, Y., St. Clair, E.M., Jernvall, J. and Daubechies, I. 2011. Comparing Dirichlet normal surface energy of tooth crowns, a new technique of molar shape quantification for dietary inference, with previous methods in isolation and in combination. American Journal of Physical Anthropology 145: 247-261.

Butler, P.M. 1946. The evolution of carnassial dentitions in the mammalia. Proceedings of the Zoological Society of London 116: 198-220.

Carlson, S.J. 1989. Vertebrate dental structures. In: J.G. Carter (Ed.), Skeletal biomineralization: patterns, processes and evolutionary trends, American Geophysical Union, Washington D. C., p. 235-260.

Caumul, R. and Polly, P.D. 2005. Phylogenetic and environmental components of morphological variation: skull, mandible, and molar shape in marmots (Marmota, Rodentia). Evolution 59: 2460-2472. 
453 Chemisquy, M.A., Prevosti, F.J., Martin, G. and Flores, D.A. 2015. Evolution of molar

454

455

456

457

458

459

460

461

462

463

464

465

466

467

468

469

470

471

472

473

474

475 shape in didelphid marsupials (Marsupialia: Didelphidae): Analysis of the influence of ecological factors and phylogenetic legacy. Zoological Journal of the Linnean Society 173: 217-235.

Chen, C., Liaw, A. and Breiman, L. 2004. Using random forest to learn imbalanced data. University of California - Berkeley web: https://statistics.berkeley.edu

Collins, K.S. and Gazley, M.F. 2017. Does my posterior look big in this? The effect of photographic distortion on morphometric analyses. Paleobiology 43: 508-520.

Cooke, S.B. 2011. Paleodiet of extinct platyrrhines with emphasis on the Caribbean forms: three-dimensional geometric morphometrics of mandibular second molars. The Anatomical Record: Advances in Integrative Anatomy and Evolutionary Biology 294: 2073-2091.

Cope, E.D. 1879. The origin of the specialized teeth of the Carnivora. The American Naturalist 13: 171-173.

Croft, D.A., Su, D.F. and Simpson, S.W. 2018a. Methods in paleoecology: reconstructing Cenozoic terrestrial environments and ecological communities. Springer, Cham, $417 \mathrm{p}$.

Croft, D.A., Engelman, R.K., Dolgushina, T. and Wesley, G. 2018b. Diversity and disparity of sparassodonts (Metatheria) reveal non-analogue nature of ancient South American mammalian carnivore guilds. Proceedings of the Royal Society B: Biological Sciences 285: 20172012.

Crusafont-Pairó, M. and Truyols-Santonja, J. 1953. Un ensayo goniométrico sobre la carnicera inferior de los Fisípedos. Estudios Geológicos 18: 225-256. 
476 Crusafont-Pairó, M. and Truyols-Santonja, J. 1956. A biometric study of the evolution of fissiped carnivores. Evolution 10: 314-332.

478

479

480

481

482

Dalerum, F. and Angerbjörn, A. 2005. Resolving temporal variation in vertebrate diets using naturally occurring stable isotopes. Oecologia 144: 647-658.

Davis, M. and Pineda Munoz, S. 2016. The temporal scale of diet and dietary proxies. Ecology and Evolution 6: 1883-1897.

Dixon, S.J. and Brereton, R.G. 2009. Comparison of performance of five common classifiers represented as boundary methods: Euclidean distance to centroids, linear discriminant analysis, quadratic discriminant analysis, learning vector quantization, and support vector machines, as dependent on. Chemometrics and Intelligent Laboratory Systems 95: 1-17.

Echarri, S., Ercoli, M.D., Chemisquy, M.A., Turazzini, G. and Prevosti, F.J. 2017. Mandible morphology and diet of the South American extinct metatherian predators (Mammalia, Metatheria, Sparassodonta). Earth and Environmental Science Transactions of the Royal Society of Edinburgh 106: 277-288.

Evans, A.R. 2013. Shape descriptors as ecometrics in dental ecology. Hystrix 24: 133140.

Evans, A.R., Fortelius, M., Jernvall, J. and Eronen, J.T. 2005. Dental ecomorphology of extant European carnivorans. In: E. Żądzińska (Ed.), Current trends in dental morphology research: 13th International symposium on dental morphology, University of Lódz Press, Lódz, p. 223-232.

Evans, A.R., Wilson, G.P., Fortelius, M. and Jernvall, J. 2007. High-level similarity of dentitions in carnivorans and rodents. Nature 445: 78-81. 
Fabre, A.-C., Cornette, R., Huyghe, K., Andrade, D. V. and Herrel, A. 2014. Linear versus geometric morphometric approaches for the analysis of head shape dimorphism in lizards. Journal of Morphology 275: 1016-1026.

Friscia, A.R., Van Valkenburgh, B. and Biknevicius, A.R. 2007. An ecomorphological analysis of extant small carnivorans. Journal of Zoology 272: 82-100.

Goin, F.J. and de los Reyes, M. 2011. Contribución al conocimiento de los representantes extintos de Lutreolina Thomas, 1910 (Mammalia, Marsupialia, Didelphidae). Historia Natural Tercera Serie 1: 15-25.

Goin, F.J., Velázquez, C. and Scaglia, O. 1992. Orientación de las crestas cortantes en el molar tribosfénico. Sus implicancias funcionales en didelfoideos (Marsupialia) fósiles y vivientes. Revista Del Museo de La Plata (Nueva Serie) 9: 183-198.

Gómez Cano, A.R., Hernández Fernández, M. and Álvarez-Sierra, M.Á. 2013. Dietary ecology of Murinae (Muridae, Rodentia): a geometric morphometric approach. PLoS ONE 8: e79080.

Harper, T., Parras, A. and Rougier, G.W. 2018. Reigitherium (Meridiolestida, Mesungulatoidea) an enigmatic Late Cretaceous mammal from Patagonia, Argentina: morphology, affinities, and dental evolution. Journal of Mammalian Evolution. DOI: 10.1007/s 10914-018-9437-x

Hogue, A.S. and Ziashakeri, S. 2010. Molar crests and body mass as dietary indicators in marsupials. Australian Journal of Zoology 58: 56-68.

Kay, R.F. 1975. The functional adaptions of primate molar teeth. American Journal of Physical Anthropology 43: 195-216. 
522 Kemsley, E.K. 1996. Discriminant analysis of high-dimensional data: a comparison of

523

524

525

526

527

528

529

530

531

532

533

534

535

536

537

538

539

540

541

542 principal components analysis and partial least squares data reduction methods. Chemometrics and Intelligent Laboratory Systems 33: 47-61.

Kissling, W.D., Dalby, L., Fløjgaard, C., Lenoir, J., Sandel, B., Sandom, C., Trøjelsgaard, K. and Svenning, J.C. 2014. Establishing macroecological trait datasets: digitalization, extrapolation, and validation of diet preferences in terrestrial mammals worldwide. Ecology and Evolution 4: 2913-2930.

Klingenberg, C.P. 2011. MorphoJ: an integrated software package for Geometric Morphometrics. Molecular Ecology Resources 11: 353-357.

Klingenberg, C.P. and Monteiro, L.R. 2005. Distances and directions in multidimensional shape spaces: implications for morphometric applications. Systematic Biology 54: 678-688.

Kovarovic, K., Aiello, L.C., Cardini, A. and Lockwood, C.A. 2011. Discriminant function analyses in archaeology: Are classification rates too good to be true? Journal of Archaeological Science 38: 3006-3018.

Lallensack, J.N., van Heteren, A.H. and Wings, O. 2016. Geometric morphometric analysis of intratrackway variability: a case study on theropod and ornithopod dinosaur trackways from Münchehagen (Lower Cretaceous, Germany). PeerJ 4: e2059.

Liaw, A. and Wiener, M. 2002. Classification and regression by randomForest. $R$ News 2: $18-22$. 
Lund, P.W. 1839. Cuop-d'oeil sur les espèces éteintes de Mammifêres du Brésil; extrait de quelques mémoires présentés à l'Académie royal des Sciences de Copenhague. Annales Des Sciences Naturelles, Zoologie 11:214-234.

Luo, Z.X. 2007. Transformation and diversification in early mammal evolution. Nature 450: 1011-1019.

Magnus, L.Z. and Cáceres, N. 2017. Phylogeny explains better than ecology or body size the variation of the first lower molar in didelphid marsupials. Mammalia 81: $119-133$.

Maroco, J., Silva, D., Rodrigues, A., Guerreiro, M., Santana, I. and de Mendonça, A. 2011. Data mining methods in the prediction of Dementia: a real-data comparison of the accuracy, sensitivity and specificity of linear discriminant analysis, logistic regression, neural networks, support vector machines, classification trees and random forests. BMC Research Notes 4: 299.

Marshall, L.G. 1978. Evolution of the Borhyaenidae, extinct South American predaceous marsupials. University of California Press, Berkeley and Los Angeles, $89 \mathrm{p}$.

Meloro, C. and Raia, P. 2010. Cats and dogs down the tree: the tempo and mode of evolution in the lower carnassial of fossil and living Carnivora. Evolutionary Biology 37: 177-186.

Meloro, C., Hudson, A. and Rook, L. 2015. Feeding habits of extant and fossil canids as determined by their skull geometry. Journal of Zoology 295: 178-188. 
564 Meloro, C., Raia, P., Piras, P., Barbera, C. and O'Higgins, P. 2008. The shape of the

565

566

567

568

569

570

571

572

573

574

575

576

577

578

579

580

581

582

583

584 mandibular corpus in large fissiped carnivores: allometry, function and phylogeny. Zoological Journal of the Linnean Society 154: 832-845.

Mitteroecker, P. and Gunz, P. 2009. Advances in geometric morphometrics. Evolutionary Biology 36: 235-247.

Mitteroecker, P. and Bookstein, F. 2011. Linear discrimination, ordination, and the visualization of selection gradients in modern morphometrics. Evolutionary Biology 38: 100-114.

Pascual, R. and Jaureguizar, E.O. 1990. Evolving climates and mammal faunas in Cenozoic South America. Journal of Human Evolution 19: 23-60.

Pineda-Munoz, S., Lazagabaster, I.A., Alroy, J. and Evans, A.R. 2017. Inferring diet from dental morphology in terrestrial mammals. Methods in Ecology and Evolution 8: 481-491.

Piras, P., Maiorino, L., Raia, P., Marcolini, F., Salvi, D., Vignoli, L. and Kotsakis, T. 2010. Functional and phylogenetic constraints in Rhinocerotinae craniodental morphology. Evolutionary Ecology Research 12: 897-928.

Popowics, T.E. 2003. Postcanine dental form in the Mustelidae and Viverridae (Carnivora: Mammalia). Journal of Morphology 256: 322-341.

Prevosti, F.J. 2006. [Grandes cánidos (Carnivora, Canidae) del Cuaternario de la República Argentina: sistemática, filogenia, bioestratigrafía y paleoecología. PhD. Thesis, Universidad Nacional de La Plata, La Plata, 501 p. Unpublished.]. 
Prevosti, F.J. and Forasiepi, A.M. 2018. Evolution of South American mammalian predators during the Cenozoic: paleobiogeographic and paleoenvironmental contingencies. Springer International Publishing, Cham, 358 p.

Prevosti, F.J., Forasiepi, A. and Zimicz, N. 2013. The evolution of the Cenozoic terrestrial mammalian predator guild in South America: competition or replacement? Journal of Mammalian Evolution 20: 3-21.

Prevosti, F.J., Turazzini, G.F., Ercoli, M.D. and Hingst-Zaher, E. 2012a. Mandible shape in marsupial and placental carnivorous mammals: a morphological comparative study using geometric morphometrics. Zoological Journal of the Linnean Society 164: 836-855.

Prevosti, F.J., Forasiepi, A.M., Ercoli, M.D. and Turazzini, G.F. 2012b. Paleoecology of the mammalian carnivores (Metatheria, Sparassodonta) of the Santa Cruz Formation (late Early Miocene). In: S.F. Vizcaíno, R.F. Kay and M.S. Bargo (Eds.), Early Miocene paleobiology in Patagonia: High-latitude paleocommunities of the Santa Cruz formation, Cambridge University Press, $\mathrm{p}$. 173-193.

Price, S.A., Hopkins, S.S.B., Smith, K.K. and Roth, V.L. 2012. Tempo of trophic evolution and its impact on mammalian diversification. Proceedings of the National Academy of Sciences 109: 7008-7012.

R Core Team. 2018. R: a language and environment for statistical computing. $R$ Foundation for Statistical Computing, Vienna, Austria. URL http://www.Rproject.org

Reig, O.A., Kirsch, J.A.W. and Marshall, L.G. 1987. Systematic relationships of the living and neocenozoic American 'opossumlike' marsupials (suborder 
Didelphimorphia), with comments on the classification of these and the Cretaceous and Paleogene New World and European Metatherians. In: M. Archer (Ed.), Possums and opossums: studies in evolution, Surrey Beatty \& Son and the Royal Zoological Society of New South Wales, Sydney, p. 1-89.

Rohlf, F.J. and Marcus, L.F. 1993. A revolution in morphometrics. Trends in Ecology and Evolution 8: 129-132.

Ryder, J.A. 1878. On the mechanical genesis of tooth-forms. Proceedings of the Academy of Natural Sciences of Philadelphia 30: 45-80.

Schmieder, D.A., Benítez, H.A., Borrissov, I.M. and Fruciano, C. 2015. Bat species comparisons based on external morphology: a test of traditional versus geometric morphometric approaches. PLoS ONE 10: e0127043.

Seetah, T.K., Cardini, A. and Miracle, P.T. 2012. Can morphospace shed light on cave bear spatial-temporal variation? Population dynamics of Ursus spelaeus from Romualdova pećina and Vindija, (Croatia). Journal of Archaeological Science 39: 500-510.

Sheets, H.D., Covino, K.M., Panasiewicz, J.M. and Morris, S.R. 2006. Comparison of geometric morphometric outline methods in the discrimination of age-related differences in feather shape. Frontiers in Zoology 3: 15.

Singleton, M., Rosenberger, A.L., Robinson, C. and O’Neill, R. 2011. Allometric and metameric shape variation in Pan mandibular molars: a digital morphometric analysis. The Anatomical Record: Advances in Integrative Anatomy and Evolutionary Biology 294: 322-334. 
631

632

633

634

635

636

637

638

639

640

641

642

643

644

645

646

647

648

649

650

651

Slice, D.E. 2007. Geometric morphometrics. Annual Review of Anthropology 36: 261281.

Smits, P.D. and Evans, A.R. 2012. Functional constraints on tooth morphology in carnivorous mammals. BMC Evolutionary Biology 12: 146.

Soibelzon, L.H., Grinspan, G.A., Bocherens, H., Acosta, W.G., Jones, W., Blanco, E.R. and Prevosti, F. 2014. South American giant short-faced bear (Arctotherium angustidens) diet: evidence from pathology, morphology, stable isotopes, and biomechanics. Journal of Paleontology 88: 1240-1250.

Solé, F. and Ladevèze, S. 2017. Evolution of the hypercarnivorous dentition in mammals (Metatheria, Eutheria) and its bearing on the development of tribosphenic molars. Evolution and Development 19: 56-68.

Strait, S.G. 1993a. Differences in occlusal morphology and molar size in frugivores and faunivores. Journal of Human Evolution 25: 471-484.

Strait, S.G. 1993b. Molar morphology and food texture among small-bodied insectivorous mammals. Journal of Mammalogy 74: 391-402.

Tarquini, S.D., Chemisquy, M.A. and Prevosti, F.J. 2018. Evolution of the carnassial in living mammalian carnivores (Carnivora, Didelphimorphia, Dasyuromorphia): diet, phylogeny, and allometry. Journal of Mammalian Evolution. doi:10.1007/s10914-018-9448-7

Ungar, P.S. 2010. Mammal teeth: origin, evolution, and diversity. The Johns Hopkins University Press, Baltimore, 304 p. 
652

653

654

655

656

657

658

659

660

661

662

663

664

665

666

667

668

669

670

671

672

673

Ungar, P.S. and M'Kirera, F. 2003. A solution to the worn tooth conundrum in primate functional anatomy. Proceedings of the National Academy of Sciences 100: 3874-3877.

Van Valen, L. 1969. Evolution of dental growth and adaptation in mammalian carnivores. Evolution 23: 96-117.

Van Valkenburgh, B. 1989. Carnivore dental adaptations and diet: a study of trophic diversity within guilds. In: J.L. Gittleman (Ed.), Carnivore behavior, ecology, and evolution. Vol. 1, Springer US, New York, p. 410-436.

Van Valkenburgh, B. 1991. Iterative evolution of hypercarnivory in canids (Mammalia: Carnivora): evolutionary interactions among sympatric predators. Paleobiology 17: $340-362$.

Van Valkenburgh, B. and Koepfli, K.-P. 1993. Cranial and dental adaptations to predation in canids. Symposia of the Zoological Society of London 65: 15-37.

Van Valkenburgh, B., Wang, X. and Damuth, J. 2004. Cope's Rule, Hypercarnivory, and extinction in North American canids. Science 306: 101-104.

Venables, W.N. and Ripley, B.D. 2002. Modern applied statistics with S, 4th ed. Springer, New York, 450 p.

Vizcaíno, S.F., Bargo, M.S. and Cassini, G.H. 2006. Dental occlusal surface area in relation to body mass, food habits and other biologic features in. Ameghiniana 43: 11-26.

Vizcaíno, S.F., Bargo, M.S., Cassini, G.H. and Toledo, N. 2016. Forma y función en paleobiología de vertebrados. EDULP, La Plata, 268 p. 
674 Wesley-Hunt, G.D. 2005. The morphological diversification of carnivores in North America. Paleobiology 31: 35-55.

676

677

678

White, J. 2009. Geometric morphometric investigation of molar shape diversity in modern lemurs and lorises. The Anatomical Record: Advances in Integrative Anatomy and Evolutionary Biology 292: 701-719.

Woodburne, M.O., Rich, T.H. and Springer, M.S. 2003. The evolution of tribospheny and the antiquity of mammalian clades. Molecular Phylogenetics and Evolution 28: $360-385$.

Zelditch, M.L., Swiderski, D.L., Sheets, H.D. and Fink, W.L. 2004. Geometric morphometrics for biologists. Academic Press, 407 p.

Zhu, J. and Pierskalla, W.P. 2016. Applying a weighted random forests method to extract karst sinkholes from LiDAR data. Journal of Hydrology 533: 343-352.

Zimicz, A.N. 2012. [Ecomorfología de los marsupiales paleógenos de América del Sur. PhD. Thesis, Universidad Nacional de La Plata, La Plata, 424p. Unpublished.].

Zimicz, N. 2014a. Paleoecología de los Bonapartherioidea (Marsupialia, Polydolopimorphia, Bonapartheriiformes). Ameghiniana 51: 106-128.

Zimicz, N. 2014b. Avoiding competition: the ecological history of late Cenozoic metatherian carnivores in South America. Journal of Mammalian Evolution 21: $383-393$.

Zuccotti, L.F., Williamson, M.D., Limp, W.F. and Ungar, P.S. 1998. Technical note: Modeling primate occlusal topography using geographic information systems technology. American Journal of Physical Anthropology 107: 137-142. 


\section{FIGURE CAPTIONS}

697 Figure 1. Diagram of landmarks and measurements taken on specimens, in labial view

698 (1) and occlusal view (2). Yellow squares, landmarks; pink circles, semi-landmarks.

699 Landmarks: 1) paraconid; 2) carnassial notch in the paracristid; 3) protoconid; 4)

700 metaconid; 5) distal edge of trigonid; 6) hypoconid; 7) entoconid; 8) mesial edge of

701 trigonid; 9) distal edge of talonid. Angle $\alpha(\boldsymbol{\alpha})$ is shown in dark red dashed lines. Lower

702 angle (AI) is shown in light blue dash-dotted lines. Measurements used for RGA are

703 green solid lines: BL, relative blade length; WT, maximum width of the talonid; LT

704 length of the talonid;

705 Figure 2. Alternative measurements taken on specimens to calculate alternative RGAs.

706 Symbols of landmarks as in Figure 1. Measurements: BL', alternative blade length; PA,

707 polygon area of the talonid. 
1

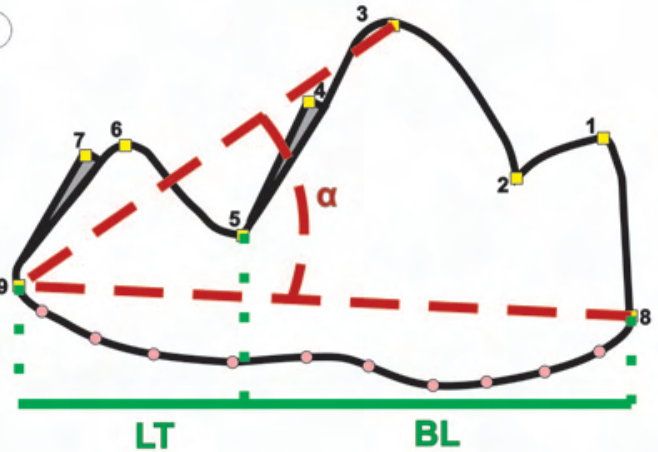

Distal $\longleftrightarrow$ Mesial

2

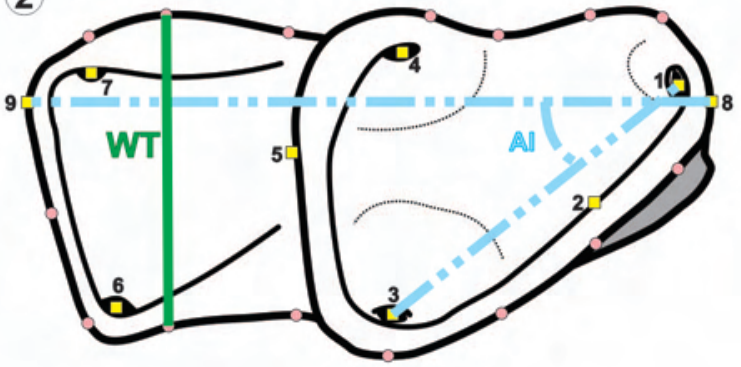




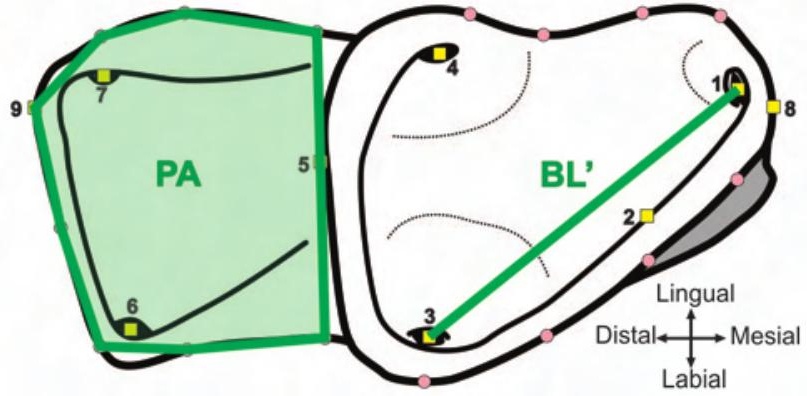


TABLE 1 - Results of the regression analyses between morphometric indices and bgPCs

\begin{tabular}{ccccccc}
\multicolumn{2}{r}{$R G A$} & & & Al & & \multicolumn{2}{c}{ Angle $\alpha$} \\
\hline$\%$ & $P$ & $\%$ & & $P$ & $\%$ & $P$
\end{tabular}

$\begin{array}{lllllll}b g P C 1 & 94.34 & <0.0001 & 64.97 & <0.0001 & 84.34<0.0001\end{array}$

$\begin{array}{lllllll}b g P C 2 & 06.92 & <0.0001 & 02.85 & 0.0104 & 18.29 & <0.0001\end{array}$

$\begin{array}{lllllll}b g P C 3 & 12.01<0.0001 & 04.31 & 0.0017 & 11.70<0.0001\end{array}$

\begin{tabular}{lllllll} 
bgPC4 & 09.21 & $<0.0001$ & 00.26 & 0.4565 & 10.84 & $<0.0001$ \\
\hline
\end{tabular}

$\%$, percentage of variance explained; $P$, probability for each analysis 
TABLE 2 - SUmmary of Confusion matrices of the different Discriminant Analyses displaying the global PCPR (Percentage of Correct Posterior Reclassification)

\begin{tabular}{cccc}
\hline & $\begin{array}{c}\text { Lineal } \\
\text { Discriminant } \\
\text { Analysis }\end{array}$ & $\begin{array}{c}\text { Quadratic } \\
\text { Discriminant } \\
\text { Analysis }\end{array}$ & $\begin{array}{c}\text { Weighted Random } \\
\text { Forests }\end{array}$ \\
\cline { 2 - 4 } 3 bg-PCs & $78.17 \%$ & $79.91 \%$ & $89.96 \%$ \\
All (3) indices & $69.43 \%$ & $72.49 \%$ & $85.59 \%$ \\
bg-PC1 & $50.22 \%$ & $60.26 \%$ & $75.98 \%$ \\
RGA & $56.33 \%$ & $57.64 \%$ & $74.67 \%$ \\
Al & $50.66 \%$ & $50.66 \%$ & $62.01 \%$ \\
Angle $\alpha$ & $46.72 \%$ & $53.28 \%$ & $65.07 \%$ \\
\hline \hline
\end{tabular}


TABLE 3 - SUmmary of Confusion matrices of the different Discriminant Analyses within Canidae displaying the global PCPR (Percentage of Correct Posterior Reclassification)

\begin{tabular}{cccc}
\hline & $\begin{array}{c}\text { Lineal } \\
\text { Discriminant } \\
\text { Analysis }\end{array}$ & $\begin{array}{c}\text { Quadratic } \\
\text { Discriminant } \\
\text { Analysis }\end{array}$ & $\begin{array}{c}\text { Weighted Random } \\
\text { Forests }\end{array}$ \\
\cline { 2 - 4 } All (2) bg-PCs indices & $90.38 \%$ & $90.38 \%$ & $92.31 \%$ \\
bg-PC1 & $71.15 \%$ & $65.38 \%$ & $69.23 \%$ \\
RGA & $86.54 \%$ & $84.62 \%$ & $75.00 \%$ \\
Al & $50.00 \%$ & $65.38 \%$ & $61.54 \%$ \\
Angle $\alpha$ & $57.69 \%$ & $57.69 \%$ & $67.31 \%$ \\
\hline \hline
\end{tabular}




\begin{tabular}{|c|c|c|c|c|}
\hline Collection number & Species & Diet & All (3) indices & $A / l(2) b g-P C s$ \\
\hline MLP-MA 1035 & Canis aureus & Mesocarnivore & Omnivore & Mesocarnivore \\
\hline MACN-MA 25123 & Canis latrans & Mesocarnivore & Hypercarnivore & Mesocarnivore \\
\hline$M L P-P V S / N$ & Canis latrans & Mesocarnivore & Omnivore & Mesocarnivore \\
\hline MLP-MA 1027 & Canis latrans & Mesocarnivore & Mesocarnivore & Mesocarnivore \\
\hline MACN-MA 23.15 & Canis lupus & Hypercarnivore & Mesocarnivore & Hypercarnivore \\
\hline MACN-MA 4256 & Canis lupus & Hypercarnivore & Mesocarnivore & Mesocarnivore \\
\hline MLP-MA 30 & Canis lupus & Hypercarnivore & Mesocarnivore & Hypercarnivore \\
\hline$A M N H(M) S / N$ & Cuon alpinus & Hypercarnivore & Hypercarnivore & Hypercarnivore \\
\hline MACN-MA 15109 & Lycalopex culpeus & Mesocarnivore & Mesocarnivore & Mesocarnivore \\
\hline MACN-MA 20813 & Lycalopex culpeus & Mesocarnivore & Mesocarnivore & Mesocarnivore \\
\hline MACN-MA 23719 & Lycalopex culpeus & Mesocarnivore & Mesocarnivore & Mesocarnivore \\
\hline MACN-MA 23915 & Lycalopex culpeus & Mesocarnivore & Mesocarnivore & Mesocarnivore \\
\hline MACN-MA 31.59 & Lycalopex culpeus & Mesocarnivore & Mesocarnivore & Mesocarnivore \\
\hline MACN-MA 38.39 & Lycalopex culpeus & Mesocarnivore & Hypercarnivore & Mesocarnivore \\
\hline$A M N H(M) S / N$ & Lycaon pictus & Hypercarnivore & Mesocarnivore & Hypercarnivore \\
\hline MACN-MA 38249 & Lycaon pictus & Hypercarnivore & Mesocarnivore & Hypercarnivore \\
\hline$A M N H(M) S / N$ & Speothos venaticus & Hypercarnivore & Hypercarnivore & Hypercarnivore \\
\hline MACN-MA 16510 & Speothos venaticus & Hypercarnivore & Mesocarnivore & Hypercarnivore \\
\hline MACN-MA 50.67 & Speothos venaticus & Hypercarnivore & Mesocarnivore & Hypercarnivore \\
\hline MACN-MA 35203 & Vulpes lagopus & Mesocarnivore & Mesocarnivore & Hypercarnivore \\
\hline MACN-MA 4.1 & Vulpes lagopus & Mesocarnivore & Hypercarnivore & Mesocarnivore \\
\hline MACN-MA 25149 & Vulpes vulpes & Mesocarnivore & Mesocarnivore & Omnivore \\
\hline MLP-MA 744 & Vulpes vulpes & Mesocarnivore & Omnivore & Mesocarnivore \\
\hline$M L P-P V S / N$ & Vulpes vulpes & Mesocarnivore & Hypercarnivore & Mesocarnivore \\
\hline
\end{tabular}




\section{The scope of traditional and geometric morphometrics for inferences of diet in carnivorous fossil mammals}

\section{Sergio D. Tarquini ${ }^{1 *}$, M. Amelia Chemisquy ${ }^{1,2}$, Sandrine Ladevèze ${ }^{3}$, and Francisco J. Prevosti ${ }^{1,2}$}

1- Centro Regional de Investigaciones Científicas y Transferencia Tecnológica de La Rioja (CRILAR - Provincia de La Rioja, UNLaR, SEGEMAR, UNCa, CONICET). Entre Ríos y Mendoza s/n (5301), Anillaco, Argentina. starquini92@gmail.com; amelych80@gmail.com; protocyon@hotmail.com

2- Departamento de Ciencias Exactas, Físicas y Naturales, Universidad Nacional de la Rioja (UNLaR). Av. Luis M. de la Fuente s/n (5300), La Rioja, Argentina.

3- Centre de Recherche en Paléontologie - Paris (CR2P - CNRS, MNHN, Sorbonne Université). 8 rue Buffon CP38 (75005), Paris, France. sandrine.ladeveze@mnhn.fr 
SUPPLEMENTARY ONLINE INFORMATION 1. Studied species and specimens and their dietary classification.

\begin{tabular}{|c|c|c|c|c|c|c|}
\hline & Species & Collection number & Digitized molar & Sex & Provenance & $\begin{array}{c}\begin{array}{c}\text { Diet } \\
\text { (reference) }\end{array} \\
\end{array}$ \\
\hline \multicolumn{7}{|c|}{ Eutheria } \\
\hline \multicolumn{7}{|c|}{ Carnivora } \\
\hline \multicolumn{7}{|c|}{ Feliformia } \\
\hline \multicolumn{7}{|c|}{ Felidae } \\
\hline \multicolumn{7}{|c|}{ Felinae } \\
\hline | & Acinonyx jubatus & MACN-MA 49.36 & $\mathrm{~m} 1$ & - & Africa & Hypercarnivore (Sunquist \& Sunquist, 2009) \\
\hline \multirow{4}{*}{\multicolumn{2}{|c|}{ Felis catus }} & MACN-MA 23688 & $\mathrm{~m} 1$ & - & - & \multirow{4}{*}{$\begin{array}{c}\text { Hypercarnivore } \\
\text { (Sunquist \& Sunquist, 2009) }\end{array}$} \\
\hline & & MACN-MA 23700 & $\mathrm{~m} 1$ & - & - & \\
\hline & & MACN-MA 23701 & $\mathrm{~m} 1$ & - & - & \\
\hline & & MACN-MA 23702 & $\mathrm{~m} 1$ & - & - & \\
\hline \multirow{6}{*}{\multicolumn{2}{|c|}{ Herpailurus yagouaroundi }} & MACN-MA 17254 & $\mathrm{~m} 1$ & o & Bolivia & \multirow{6}{*}{$\begin{array}{c}\text { Hypercarnivore } \\
\text { (Sunquist \& Sunquist, 2009) }\end{array}$} \\
\hline & & MACN-MA 23692 & $\mathrm{~m} 1$ & q & Misiones, Argentina & \\
\hline & & MACN-MA 25772 & $\mathrm{~m} 1$ & $\hat{0}$ & Salta, Argentina & \\
\hline & & MACN-MA 33.4 & $\mathrm{~m} 1$ & $\hat{0}$ & Mendoza, Argentina & \\
\hline & & MACN-MA 50104 & $\mathrm{~m} 1$ & $\hat{o}$ & - & \\
\hline & & MACN-MA 50555 & $\mathrm{~m} 1$ & $\hat{o}$ & Misiones, Argentina & \\
\hline \multirow{5}{*}{\multicolumn{2}{|c|}{ Leopardus colocolo }} & MACN-MA 16489 & $\mathrm{~m} 1$ & - & Neuquén, Argentina & \multirow{5}{*}{$\begin{array}{c}\text { Hypercarnivore } \\
\text { (Sunquist \& Sunquist, 2009) }\end{array}$} \\
\hline & & MACN-MA 22928 & $\mathrm{~m} 1$ & 우 & Salta, Argentina & \\
\hline & & MACN-MA 22934 & $\mathrm{~m} 1$ & - & Santa Cruz, Argentina & \\
\hline & & MACN-MA 23176 & $\mathrm{~m} 1$ & - & La Pampa, Argentina & \\
\hline & & MACN-MA 30103 & $\mathrm{~m} 1$ & $\hat{0}$ & Neuquén, Argentina & \\
\hline \multirow{2}{*}{\multicolumn{2}{|c|}{ Leopardus geoffroyi }} & MACN-MA 15425 & $\mathrm{~m} 1$ & $\hat{0}$ & Córdoba, Argentina & \multirow{2}{*}{$\begin{array}{c}\text { Hypercarnivore } \\
\text { (Sunquist \& Sunquist, 2009) }\end{array}$} \\
\hline & & MACN-MA 22022 & $\mathrm{~m} 1$ & - & Bs. As., Argentina & \\
\hline
\end{tabular}




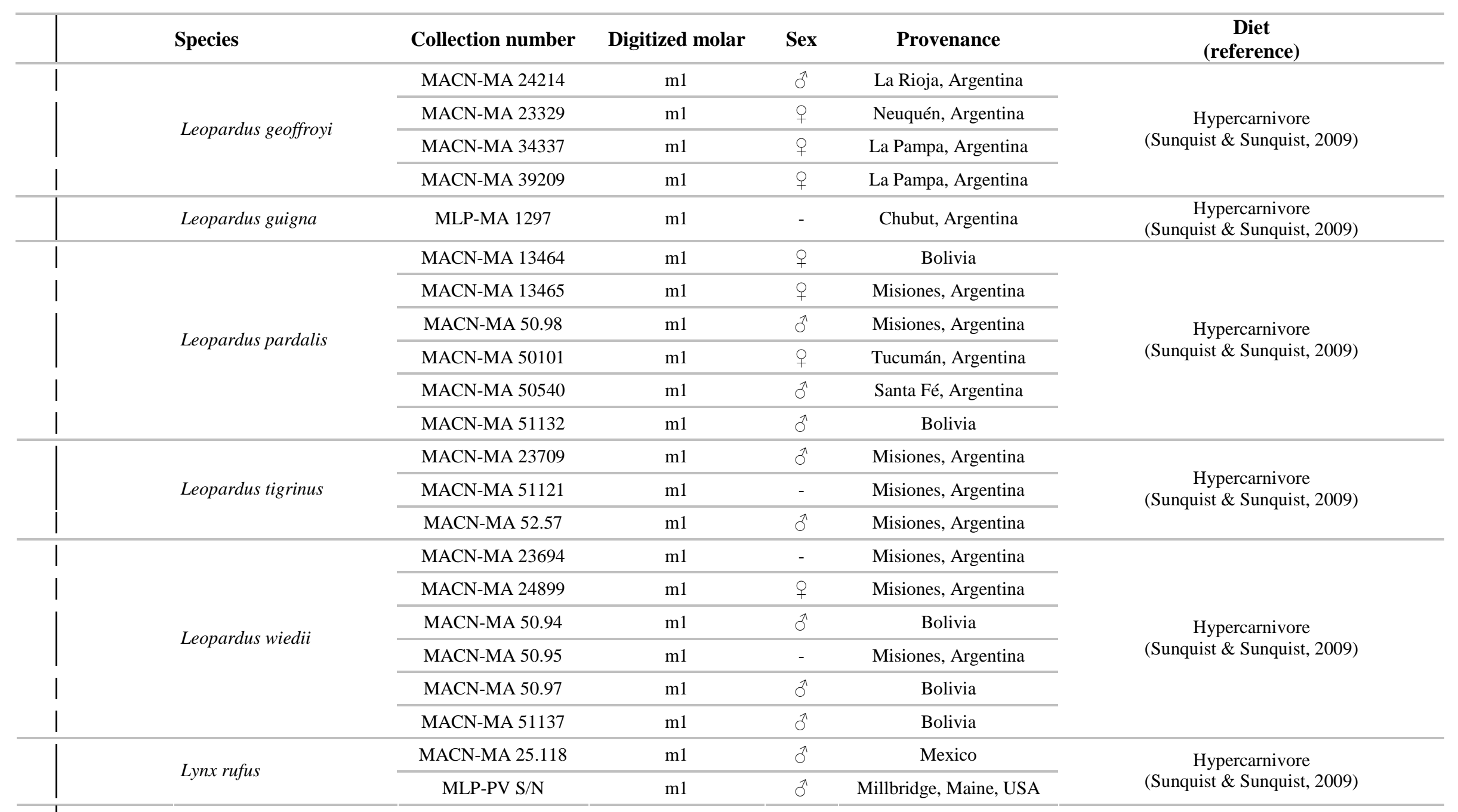




\begin{tabular}{|c|c|c|c|c|c|}
\hline Species & Collection number & Digitized molar & Sex & Provenance & $\begin{array}{c}\text { Diet } \\
\text { (reference) }\end{array}$ \\
\hline \multirow{6}{*}{ Puma concolor } & MACN-MA 13339 & $\mathrm{~m} 1$ & - & San Luis, Argentina & \multirow{6}{*}{$\begin{array}{c}\text { Hypercarnivore } \\
\text { (Sunquist \& Sunquist, 2009) }\end{array}$} \\
\hline & MACN-MA 20629 & $\mathrm{~m} 1$ & - & La Pampa, Argentina & \\
\hline & MACN-MA 30250 & $\mathrm{~m} 1$ & $\hat{0}$ & Neuquén, Argentina & \\
\hline & MACN-MA 32.80 & $\mathrm{~m} 1$ & q & San Luis, Argentina & \\
\hline & MACN-MA 36614 & $\mathrm{~m} 1$ & $\hat{0}$ & Santa Cruz, Argentina & \\
\hline & MACN-MA 49295 & $\mathrm{~m} 1$ & - & Salta, Argentina & \\
\hline \multicolumn{6}{|l|}{ Pantherinae } \\
\hline \multirow{6}{*}{ Panthera leo } & MACN-MA 23.1 & $\mathrm{~m} 1$ & - & Africa & \multirow{6}{*}{$\begin{array}{c}\text { Hypercarnivore } \\
\text { (Sunquist \& Sunquist, 2009) }\end{array}$} \\
\hline & MACN-MA 25158 & $\mathrm{~m} 1$ & - & Africa & \\
\hline & MACN-MA 29904 & $\mathrm{~m} 1$ & q & Africa & \\
\hline & MACN-MA 4254 & $\mathrm{~m} 1$ & - & Africa & \\
\hline & MACN-MA 4330 & $\mathrm{~m} 1$ & - & Africa & \\
\hline & MACN-MA 4337 & $\mathrm{~m} 1$ & - & Africa & \\
\hline \multirow{6}{*}{ Panthera onca } & MACN-MA 21622 & $\mathrm{~m} 1$ & - & Misiones, Argentina & \multirow{6}{*}{$\begin{array}{c}\text { Hypercarnivore } \\
\text { (Sunquist \& Sunquist, 2009) }\end{array}$} \\
\hline & MACN-MA 25.66 & $\mathrm{~m} 1$ & - & Misiones, Argentina & \\
\hline & MACN-MA 25769 & $\mathrm{~m} 1$ & q & Tucumán, Argentina & \\
\hline & MACN-MA 4301 & $\mathrm{~m} 1$ & - & South America & \\
\hline & MACN-MA 7.8 & $\mathrm{~m} 1$ & - & Bolivia & \\
\hline & MACN-MA 8.43 & $\mathrm{~m} 1$ & - & Bolivia & \\
\hline Panthera pardus & MLP-MA 1040 & $\mathrm{~m} 1$ & - & Africa & $\begin{array}{c}\text { Hypercarnivore } \\
\text { (Sunquist \& Sunquist, 2009) }\end{array}$ \\
\hline \multirow{4}{*}{ Panthera tigris } & MACN-MA 25.54 & $\mathrm{~m} 1$ & - & Sumatra & \multirow{4}{*}{$\begin{array}{c}\text { Hypercarnivore } \\
\text { (Sunquist \& Sunquist, 2009) }\end{array}$} \\
\hline & MACN-MA 26.83 & $\mathrm{~m} 1$ & - & India & \\
\hline & MLP-MA 1048 & $\mathrm{~m} 1$ & - & - & \\
\hline & MLP-MA 1051 & $\mathrm{~m} 1$ & - & - & \\
\hline
\end{tabular}




\begin{tabular}{|c|c|c|c|c|c|}
\hline Species & Collection number & Digitized molar & Sex & Provenance & $\begin{array}{c}\text { Diet } \\
\text { (reference) }\end{array}$ \\
\hline \multirow{2}{*}{ Panthera tigris } & MLP-MA 112 & $\mathrm{~m} 1$ & - & India & \multirow{2}{*}{$\begin{array}{c}\text { Hypercarnivore } \\
\text { (Sunquist \& Sunquist, 2009) }\end{array}$} \\
\hline & MLP-MA 11-IV-48-1 & $\mathrm{m} 1$ & - & - & \\
\hline Panthera uncia & MACN-MA 8.23 & $\mathrm{~m} 1$ & - & Asia & $\begin{array}{c}\text { Hypercarnivore } \\
\text { (Sunquist \& Sunquist, 2009) }\end{array}$ \\
\hline \multicolumn{6}{|l|}{ Herpestidae } \\
\hline \multicolumn{6}{|l|}{ Herpestinae } \\
\hline \multirow{2}{*}{ Herpestes ichneumon } & MLP-MA 1029 & $\mathrm{~m} 1$ & - & Africa & \multirow{2}{*}{$\begin{array}{c}\text { Hypercarnivore } \\
\text { (Rosalino et al., 2009) }\end{array}$} \\
\hline & MLP-MA 1323 & $\mathrm{~m} 1$ & - & Africa & \\
\hline \multicolumn{6}{|l|}{ Hyaenidae } \\
\hline \multicolumn{6}{|l|}{ Hyaeninae } \\
\hline \multirow{2}{*}{ Crocuta crocuta } & MACN-MA 24525 & $\mathrm{~m} 1$ & - & Africa & \multirow{2}{*}{$\begin{array}{c}\text { Hypercarnivore } \\
\text { (Holekamp \& Kolowski, 2009) }\end{array}$} \\
\hline & MACN-MA 33277 & $\mathrm{~m} 1$ & - & Africa & \\
\hline \multirow{4}{*}{ Hyaena hyaena } & MACN-MA 15.28 & $\mathrm{~m} 1$ & - & Africa & \multirow{4}{*}{$\begin{array}{c}\text { Mesocarnivore } \\
\text { (Holekamp \& Kolowski, 2009) }\end{array}$} \\
\hline & MACN-MA 25103 & $\mathrm{~m} 1$ & - & Africa & \\
\hline & MACN-MA 4.6 & $\mathrm{~m} 1$ & - & Africa & \\
\hline & MLP-MA 1039 & $\mathrm{~m} 1$ & - & - & \\
\hline \multicolumn{6}{|l|}{ Viverridae } \\
\hline \multicolumn{6}{|l|}{ Genettinae } \\
\hline \multirow{2}{*}{ Genetta genetta } & MACN-MA 21104 & $\mathrm{~m} 1$ & - & Spain & \multirow{2}{*}{$\begin{array}{l}\text { Mesocarnivore } \\
\text { (Torre } \text { et al., 2003) }\end{array}$} \\
\hline & MACN-MA 21105 & $\mathrm{~m} 1$ & - & Spain & \\
\hline
\end{tabular}




\begin{tabular}{|c|c|c|c|c|c|c|}
\hline & Species & Collection number & Digitized molar & Sex & Provenance & $\begin{array}{c}\text { Diet } \\
\text { (reference) }\end{array}$ \\
\hline & \multirow{3}{*}{ Genetta genetta } & MACN-MA 21106 & $\mathrm{~m} 1$ & - & Spain & \multirow{3}{*}{$\begin{array}{c}\text { Mesocarnivore } \\
\text { (Torre } \text { et al., 2003) }\end{array}$} \\
\hline & & MACN-MA 21107 & $\mathrm{~m} 1$ & - & Spain & \\
\hline & & MACN-MA 23.43 & $\mathrm{~m} 1$ & - & Africa & \\
\hline \multicolumn{7}{|c|}{ |Caniformia } \\
\hline & \multicolumn{6}{|l|}{ Canidae } \\
\hline & Canis aureus & MLP-MA 1035 & $\mathrm{~m} 1$ & - & - & Mesocarnivore (Sillero-Zubiri, 2009) \\
\hline & \multirow{3}{*}{ Canis latrans } & MACN-MA 25123 & $\mathrm{~m} 1$ & - & North America & \multirow{3}{*}{$\begin{array}{c}\text { Mesocarnivore } \\
\text { (Sillero-Zubiri, 2009) }\end{array}$} \\
\hline & & MLP-MA 1027 & $\mathrm{~m} 1$ & - & Africa & \\
\hline & & MLP-PV S/N & $\mathrm{m} 1$ & - & South Dakota, USA & \\
\hline & \multirow{3}{*}{ Canis lupus } & MACN-MA 23.15 & $\mathrm{~m} 1$ & - & Russia & \multirow{3}{*}{$\begin{array}{c}\text { Hypercarnivore } \\
\text { (Sillero-Zubiri, 2009) }\end{array}$} \\
\hline & & MACN-MA 4256 & $\mathrm{~m} 1$ & - & Europe & \\
\hline & & MLP-MA 30 & $\mathrm{~m} 1$ & - & - & \\
\hline & \multirow{6}{*}{ Cerdocyon thous } & MACN-MA 14322 & $\mathrm{~m} 1$ & $\hat{0}$ & Santa Fe, Argentina & \multirow{6}{*}{$\begin{array}{c}\text { Omnivore } \\
\text { (Sillero-Zubiri, 2009) }\end{array}$} \\
\hline & & MACN-MA 14681 & $\mathrm{~m} 1$ & 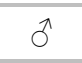 & Salta, Argentina & \\
\hline & & MACN-MA 16189 & $\mathrm{~m} 1$ & $\hat{0}$ & Misiones, Argentina & \\
\hline & & MACN-MA 20456 & $\mathrm{~m} 1$ & q & Salta, Argentina & \\
\hline & & MACN-MA 48.10 & $\mathrm{~m} 1$ & o & Salta, Argentina & \\
\hline & & MACN-MA 50.61 & $\mathrm{~m} 1$ & q & Bolivia & \\
\hline & \multirow{6}{*}{ Chrysocyon brachyurus } & MACN-MA 19146 & $\mathrm{~m} 1$ & - & - & \multirow{6}{*}{$\begin{array}{c}\text { Omnivore } \\
\text { (Sillero-Zubiri, 2009) }\end{array}$} \\
\hline & & MACN-MA 23984 & $\mathrm{~m} 1$ & - & Corrientes, Argentina & \\
\hline & & MACN-MA 24043 & $\mathrm{~m} 1$ & - & Corrientes, Argentina & \\
\hline & & MACN-MA 24750 & $\mathrm{~m} 1$ & - & Paraguay & \\
\hline & & MACN-MA 3.73 & $\mathrm{~m} 1$ & - & - & \\
\hline & & MACN-MA 53.49 & $\mathrm{~m} 1$ & - & - & \\
\hline
\end{tabular}




\begin{tabular}{|c|c|c|c|c|c|c|}
\hline & Species & Collection number & Digitized molar & Sex & Provenance & $\begin{array}{c}\text { Diet } \\
\text { (reference) }\end{array}$ \\
\hline & Cuon alpinus & $\mathrm{AMNH}(\mathrm{M}) \mathrm{S} / \mathrm{N}$ & $\mathrm{m} 1$ & - & & $\begin{array}{c}\text { Hypercarnivore } \\
\text { (Sillero-Zubiri, 2009) }\end{array}$ \\
\hline & \multirow{6}{*}{ Lycalopex culpaeus } & MACN-MA 15109 & $\mathrm{~m} 1$ & $\hat{0}$ & Neuquén, Argentina & \multirow{6}{*}{$\begin{array}{c}\text { Mesocarnivore } \\
\text { (Sillero-Zubiri, 2009) }\end{array}$} \\
\hline | & & MACN-MA 20813 & $\mathrm{~m} 1$ & $\hat{0}$ & Neuquén, Argentina & \\
\hline & & MACN-MA 23719 & $\mathrm{~m} 1$ & $\hat{0}$ & Jujuy, Argentina & \\
\hline & & MACN-MA 23915 & $\mathrm{~m} 1$ & 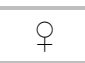 & Ecuador & \\
\hline | & & MACN-MA 31.59 & $\mathrm{~m} 1$ & - & - & \\
\hline | & & MACN-MA 38.39 & $\mathrm{~m} 1$ & - & - & \\
\hline | & \multirow{6}{*}{ Lycalopex griseus } & MACN-MA 15186 & $\mathrm{~m} 1$ & $\hat{0}$ & Neuquén, Argentina & \multirow{6}{*}{$\begin{array}{c}\text { Omnivore } \\
\text { (Sillero-Zubiri, 2009) }\end{array}$} \\
\hline | & & MACN-MA 20205 & $\mathrm{~m} 1$ & o & Río Negro, Argentina & \\
\hline . & & MACN-MA 20207 & $\mathrm{~m} 1$ & $\hat{\sigma}$ & Río Negro, Argentina & \\
\hline & & MACN-MA 20278 & $\mathrm{~m} 1$ & q & Río Negro, Argentina & \\
\hline | & & MACN-MA 20814 & $\mathrm{~m} 1$ & q & Río Negro, Argentina & \\
\hline | & & MACN-MA 36480 & $\mathrm{~m} 1$ & q & Salta, Argentina & \\
\hline | & \multirow{6}{*}{ Lycalopex gymnocercus } & MACN-MA 14319 & $\mathrm{~m} 1$ & o & La Pampa, Argentina & \multirow{6}{*}{$\begin{array}{c}\text { Omnivore } \\
\text { (Sillero-Zubiri, 2009) }\end{array}$} \\
\hline | & & MACN-MA 16041 & $\mathrm{~m} 1$ & $\hat{0}$ & Córdoba, Argentina & \\
\hline & & MACN-MA 16049 & $\mathrm{~m} 1$ & $\hat{\sigma}$ & La Pampa, Argentina & \\
\hline & & MACN-MA 29.35 & $\mathrm{~m} 1$ & q & La Pampa, Argentina & \\
\hline | & & MACN-MA 49134 & $\mathrm{~m} 1$ & q & Salta, Argentina & \\
\hline | & & MACN-MA 49148 & $\mathrm{~m} 1$ & q & La Pampa, Argentina & \\
\hline 1 & Lycalopex vetulus & MLP-PV S/N & $\mathrm{m} 1$ & - & Brazil & Omnivore (Sillero-Zubiri, 2009) \\
\hline & \multirow{2}{*}{ Lycaon pictus } & $\mathrm{AMNH}(\mathrm{M}) \mathrm{S} / \mathrm{N}$ & $\mathrm{m} 1$ & - & Africa & \multirow{2}{*}{$\begin{array}{c}\text { Hypercarnivore } \\
\text { (Sillero-Zubiri, 2009) }\end{array}$} \\
\hline & & MACN-MA 38249 & $\mathrm{~m} 1$ & - & Africa & \\
\hline
\end{tabular}




\begin{tabular}{|c|c|c|c|c|c|}
\hline Species & Collection number & Digitized molar & Sex & Provenance & $\begin{array}{c}\text { Diet } \\
\text { (reference) }\end{array}$ \\
\hline \multirow{3}{*}{ Speothos venaticus } & $\mathrm{AMNH}(\mathrm{M}) \mathrm{S} / \mathrm{N}$ & $\mathrm{m} 1$ & - & - & \multirow{3}{*}{$\begin{array}{c}\text { Hypercarnivore } \\
\text { (Sillero-Zubiri, 2009) }\end{array}$} \\
\hline & MACN-MA 16510 & $\mathrm{~m} 1$ & $\hat{0}$ & Misiones, Argentina & \\
\hline & MACN-MA 50.67 & $\mathrm{~m} 1$ & $\hat{0}$ & Bolivia & \\
\hline \multirow{2}{*}{ Urocyon cinereoargenteus } & MACN-MA 6.33 & $\mathrm{~m} 1$ & - & USA & \multirow{2}{*}{$\begin{array}{c}\text { Omnivore } \\
\text { (Sillero-Zubiri, 2009) }\end{array}$} \\
\hline & MLP-PV S/N & $\mathrm{m} 1$ & - & Massachusetts, USA & \\
\hline \multirow{2}{*}{ Vulpes lagopus } & MACN-MA 35203 & $\mathrm{~m} 1$ & - & Russia & \multirow{2}{*}{$\begin{array}{c}\text { Mesocarnivore } \\
\text { (Sillero-Zubiri, 2009) }\end{array}$} \\
\hline & MACN-MA 4.1 & $\mathrm{~m} 1$ & - & Russia & \\
\hline \multirow{3}{*}{ Vulpes vulpes } & MACN-MA 25149 & $\mathrm{~m} 1$ & - & Germany & \multirow{3}{*}{$\begin{array}{c}\text { Mesocarnivore } \\
\text { (Padial et al., 2002) }\end{array}$} \\
\hline & MLP-MA 744 & $\mathrm{~m} 1$ & - & Rome, Italy & \\
\hline & MLP-PV S/N & $\mathrm{m} 1$ & $\hat{0}$ & Massachusetts, USA & \\
\hline Vulpes zerda & MACN-MA 9.14 & $\mathrm{~m} 1$ & - & Africa & $\begin{array}{c}\text { Omnivore } \\
\text { (Sillero-Zubiri, 2009) }\end{array}$ \\
\hline \multicolumn{6}{|l|}{ Ursidae } \\
\hline \multicolumn{6}{|l|}{ Ailuropodinae } \\
\hline Ailuropoda melanoleuca & $\begin{array}{l}\text { MNHN-ZM-AC 1874- } \\
273\end{array}$ & $\mathrm{~m} 1$ & - & Tibet, China & Herbivore (Garshelis, 2009) \\
\hline \multicolumn{6}{|l|}{ Tremarctinae } \\
\hline \multirow{2}{*}{ Tremarctos ornatus } & MACN-MA 17830 & $\mathrm{~m} 1$ & $\hat{0}$ & Bolivia & \multirow{2}{*}{ Herbivore (Garshelis, 2009) } \\
\hline & MACN-MA 50.87 & $\mathrm{~m} 1$ & - & Bolivia & \\
\hline \multicolumn{6}{|l|}{ Ursinae } \\
\hline Helarctos malayanus & MACN-MA 25.49 & $\mathrm{~m} 1$ & - & Indonesia & Omnivore (Garshelis, 2009) \\
\hline Ursus americanus & MLP-MA 1011 & $\mathrm{~m} 1$ & - & - & Omnivore (Garshelis, 2009) \\
\hline Ursus arctos & MACN-MA 35208 & $\mathrm{~m} 1$ & 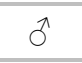 & Russia & Omnivore (Garshelis, 2009) \\
\hline \multirow{2}{*}{ Ursus maritimus } & MACN-MA 26124 & $\mathrm{~m} 1$ & - & Norway & \multirow{2}{*}{$\begin{array}{l}\text { Hypercarnivore } \\
\text { (Garshelis, 2009) }\end{array}$} \\
\hline & MACN-MA 33.94 & $\mathrm{~m} 1$ & - & Norway & \\
\hline
\end{tabular}




\begin{tabular}{|c|c|c|c|c|c|}
\hline Species & Collection number & Digitized molar & Sex & Provenance & $\begin{array}{c}\text { Diet } \\
\text { (reference) }\end{array}$ \\
\hline \multirow{2}{*}{ Ursus maritimus } & MACN-MA 35204 & $\mathrm{~m} 1$ & - & Russia & \multirow{2}{*}{$\begin{array}{l}\text { Hypercarnivore } \\
\text { (Garshelis, 2009) }\end{array}$} \\
\hline & MLP-MA 1004 & $\mathrm{~m} 1$ & - & - & \\
\hline \multirow{2}{*}{\multicolumn{6}{|c|}{$\begin{array}{l}\text { Mephitidae } \\
\text { Mephitinae }\end{array}$}} \\
\hline & & & & & \\
\hline \multirow{7}{*}{ Conepatus chinga } & MACN-MA 13499 & $\mathrm{~m} 1$ & 우뇨 & Corrientes, Argentina & \multirow{7}{*}{$\begin{array}{c}\text { Omnivore } \\
\text { (Dragoo, 2009) }\end{array}$} \\
\hline & MACN-MA 13714 & $\mathrm{~m} 1$ & $\hat{0}$ & Salta, Argentina & \\
\hline & MACN-MA 23992 & $\mathrm{~m} 1$ & - & Uruguay & \\
\hline & MACN-MA 24002 & $\mathrm{~m} 1$ & - & Río Negro, Argentina & \\
\hline & MACN-MA 24006 & $\mathrm{~m} 1$ & - & Río Negro, Argentina & \\
\hline & MACN-MA 24719 & $\mathrm{~m} 1$ & - & Río Negro, Argentina & \\
\hline & MACN-MA 30393 & $\mathrm{~m} 1$ & $\hat{0}$ & $\begin{array}{l}\text { Catán-Lil, Neuquén, } \\
\text { Argentina }\end{array}$ & \\
\hline \multirow{3}{*}{ Mephitis mephitis } & MACN-MA 23520 & $\mathrm{~m} 1$ & 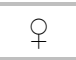 & USA & \multirow{3}{*}{$\begin{array}{c}\text { Omnivore } \\
\text { (Dragoo, 2009) }\end{array}$} \\
\hline & MACN-MA 23521 & $\mathrm{~m} 1$ & $\hat{0}$ & USA & \\
\hline & MLP-PV S/N & $\mathrm{m} 1$ & q & Massachusetts, USA & \\
\hline \multirow{2}{*}{ Spilogale gracilis } & MACN-MA 34551 & $\mathrm{~m} 1$ & $\delta$ & USA & \multirow{2}{*}{$\begin{array}{c}\text { Omnivore } \\
\text { (Dragoo, 2009) }\end{array}$} \\
\hline & MACN-MA 34552 & $\mathrm{~m} 1$ & q & USA & \\
\hline
\end{tabular}

\section{Mustelidae}

Ictonychinae

Galictis cuja

\begin{tabular}{cccc} 
MACN-MA 13498 & $\mathrm{~m} 1$ & $\AA$ & $\begin{array}{c}\text { El Bolson, Río Negro, } \\
\text { Argentina }\end{array}$ \\
\hline MACN-MA 13965 & $\mathrm{~m} 1$ & $\wp$ & $\begin{array}{c}\text { Catán-Lil, Neuquén, } \\
\text { Argentina }\end{array}$ \\
\hline MACN-MA 16254 & $\mathrm{~m} 1$ & + & Bs. As., Argentina \\
\hline MACN-MA 16520 & $\mathrm{~m} 1$ & $\curvearrowright$ & $\begin{array}{c}\text { Cushamen, Chubut, } \\
\text { Argentina }\end{array}$ \\
\hline
\end{tabular}




\begin{tabular}{|c|c|c|c|c|c|}
\hline Species & Collection number & Digitized molar & Sex & Provenance & $\begin{array}{c}\text { Diet } \\
\text { (reference) }\end{array}$ \\
\hline \multirow{2}{*}{ Galictis cuja } & MACN-MA 23291 & $\mathrm{~m} 1$ & $\hat{\jmath}$ & Bs. As., Argentina & \multirow{2}{*}{$\begin{array}{c}\text { Hypercarnivore } \\
\text { (Larivière \& Jennings, 2009) }\end{array}$} \\
\hline & MACN-MA 23793 & $\mathrm{~m} 1$ & - & Bs. As., Argentina & \\
\hline Galictis vittata & MACN-MA 50.91 & $\mathrm{~m} 1$ & 운묘 & Bolivia & $\begin{array}{c}\text { Hypercarnivore } \\
\text { (Larivière \& Jennings, 2009) }\end{array}$ \\
\hline Ictionyx libyca & MACN-MA 24.12 & $\mathrm{~m} 1$ & - & Africa & Mesocarnivore (Larivière \& Jennings, 2009) \\
\hline \multirow[b]{2}{*}{ Lyncodon patagonicus } & MACN-MA 31214 & $\mathrm{~m} 1$ & $\hat{0}$ & $\begin{array}{c}\text { Patquía, La Rioja, } \\
\text { Argentina }\end{array}$ & \multirow{2}{*}{$\begin{array}{c}\text { Hypercarnivore } \\
\text { (Larivière \& Jennings, 2009) }\end{array}$} \\
\hline & $\begin{array}{l}\text { MLP-MA 29-XII-00- } \\
17\end{array}$ & $\mathrm{~m} 1$ & - & Río Negro, Argentina & \\
\hline \multicolumn{6}{|l|}{ Lutrinae } \\
\hline Lontra felina & MACN-MA 34602 & $\mathrm{~m} 1$ & - & $\begin{array}{c}\text { Isla de los Estados, } \\
\text { Argentina }\end{array}$ & Piscivore (Kruuk, 2006) \\
\hline \multirow{9}{*}{ Lontra longicaudi } & MACN-MA 13073 & $\mathrm{~m} 1$ & $\hat{0}$ & Misiones, Argentina & \multirow{9}{*}{$\begin{array}{c}\text { Piscivore } \\
\text { (Kruuk, 2006) }\end{array}$} \\
\hline & MACN-MA 24.13 & $\mathrm{~m} 1$ & q & Paraguay & \\
\hline & MACN-MA 24662 & $\mathrm{~m} 1$ & - & - & \\
\hline & MACN-MA 24665 & $\mathrm{~m} 1$ & - & America & \\
\hline & MACN-MA 24666 & $\mathrm{~m} 1$ & q & $\begin{array}{l}\text { Delta del Paraná, } \\
\text { Argentina }\end{array}$ & \\
\hline & MACN-MA 25357 & $\mathrm{~m} 1$ & q & Bs. As., Argentina & \\
\hline & MACN-MA 30234 & $\mathrm{~m} 1$ & - & Chaco, Argentina & \\
\hline & MACN-MA 30246 & $\mathrm{~m} 1$ & - & Chaco, Argentina & \\
\hline & MACN-MA 5.11 & $\mathrm{~m} 1$ & - & Santa Fé, Argentina & \\
\hline Lontra provocax & MLP-MA 1282 & $\mathrm{~m} 1$ & - & $\begin{array}{l}\text { Tierra del Fuego, } \\
\text { Argentina }\end{array}$ & Piscivore (Kruuk, 2006) \\
\hline \multirow{2}{*}{ Pteronura braziliensis } & MACN-MA 25783 & $\mathrm{~m} 1$ & - & - & \multirow{2}{*}{$\begin{array}{c}\text { Piscivore } \\
\text { (Kruuk, 2006) }\end{array}$} \\
\hline & MACN-MA 33155 & $\mathrm{~m} 1$ & - & Bolivia & \\
\hline
\end{tabular}




\begin{tabular}{|c|c|c|c|c|c|}
\hline Species & Collection number & Digitized molar & Sex & Provenance & $\begin{array}{c}\text { Diet } \\
\text { (reference) }\end{array}$ \\
\hline Guloninae & & & & & \multirow{7}{*}{$\begin{array}{c}\text { Omnivore } \\
\text { (Larivière \& Jennings, 2009) }\end{array}$} \\
\hline \multirow{6}{*}{ Eira barbara } & MACN-MA 20457 & $\mathrm{~m} 1$ & $\hat{0}$ & $\begin{array}{c}\text { Iguazú, Misiones, } \\
\text { Argentina }\end{array}$ & \\
\hline & MACN-MA 31.61 & $\mathrm{~m} 1$ & q & Bolivia & \\
\hline & MACN-MA 47202 & $\mathrm{~m} 1$ & q & Bolivia & \\
\hline & MACN-MA 50.90 & $\mathrm{~m} 1$ & q & Misiones, Argentina & \\
\hline & MACN-MA 50.92 & $\mathrm{~m} 1$ & $\hat{0}$ & Salta, Argentina & \\
\hline & MACN-MA 52.38 & $\mathrm{~m} 1$ & $\hat{o}$ & Ecuador & \\
\hline Martes martes & MACN-MA 4.50 & $\mathrm{~m} 1$ & - & - & Mesocarnivore (Larivière \& Jennings, 2009) \\
\hline \multicolumn{6}{|l|}{ Melinae } \\
\hline \multirow{3}{*}{ Meles meles } & MACN-MA 41227 & $\mathrm{~m} 1$ & - & Europe & \multirow{3}{*}{$\begin{array}{c}\text { Omnivore } \\
\text { (Larivière \& Jennings, 2009) }\end{array}$} \\
\hline & MACN-MA 4250 & $\mathrm{~m} 1$ & - & Southern Europe & \\
\hline & MACN-MA 5.36 & $\mathrm{~m} 1$ & - & Europe & \\
\hline \multicolumn{6}{|l|}{ Mustelinae } \\
\hline Mustela eversmanni & MACN-MA 35206 & $\mathrm{~m} 1$ & - & Russia & Hypercarnivore (Larivière \& Jennings, 2009) \\
\hline Mustela nivalis & MLP-MA 1018 & $\mathrm{~m} 1$ & - & Europe & Hypercarnivore (Larivière \& Jennings, 2009) \\
\hline \multirow{3}{*}{ Mustela putorius } & MACN-MA 20645 & $\mathrm{~m} 1$ & - & Spain & \multirow{3}{*}{$\begin{array}{c}\text { Hypercarnivore } \\
\text { (Larivière \& Jennings, 2009) }\end{array}$} \\
\hline & MACN-MA 25148 & $\mathrm{~m} 1$ & - & Europe & \\
\hline & MLP-MA 6-111-36-35 & $\mathrm{m} 1$ & - & Spain & \\
\hline Mustela sibirica & MACN-MA 35207 & $\mathrm{~m} 1$ & $\hat{0}$ & Russia & Hypercarnivore (Larivière \& Jennings, 2009) \\
\hline \multirow{4}{*}{ Neovison vison } & MACN-MA 16327 & $\mathrm{~m} 1$ & $\hat{\sigma}$ & Chubut, Argentina & \multirow{4}{*}{$\begin{array}{c}\text { Hypercarnivore } \\
\text { (Larivière \& Jennings, 2009) }\end{array}$} \\
\hline & MACN-MA 17825 & $\mathrm{~m} 1$ & $\hat{0}$ & Bs. As., Argentina & \\
\hline & MACN-MA 17826 & $\mathrm{~m} 1$ & $\hat{0}$ & Chubut, Argentina & \\
\hline & MACN-MA 19186 & $\mathrm{~m} 1$ & q & Bs. As., Argentina & \\
\hline
\end{tabular}




\begin{tabular}{|c|c|c|c|c|c|}
\hline Species & Collection number & Digitized molar & Sex & Provenance & $\begin{array}{c}\text { Diet } \\
\text { (reference) }\end{array}$ \\
\hline \multirow{2}{*}{ Neovison vison } & MACN-MA 19187 & $\mathrm{~m} 1$ & q & Bs. As., Argentina & \multirow{2}{*}{$\begin{array}{c}\text { Hypercarnivore } \\
\text { (Larivière \& Jennings, 2009) }\end{array}$} \\
\hline & MACN-MA 19188 & $\mathrm{~m} 1$ & 우 & Chubut, Argentina & \\
\hline \multicolumn{6}{|l|}{ Taxidiinae } \\
\hline Taxidea taxus & MLP-PV S/N & $\mathrm{m} 1$ & - & - & Mesocarnivore (Larivière \& Jennings, 2009) \\
\hline \multicolumn{6}{|l|}{ Procyonidae } \\
\hline \multirow{3}{*}{ Bassaricyon alleni } & MACN-MA 31.68 & $\mathrm{~m} 1$ & - & Ecuador & \multirow{3}{*}{$\begin{array}{c}\text { Herbivore } \\
\text { (Kays, 2009) }\end{array}$} \\
\hline & MACN-MA 50.81 & $\mathrm{~m} 1$ & $\hat{0}$ & Bolivia & \\
\hline & MACN-MA 50.82 & $\mathrm{~m} 1$ & $\hat{0}$ & Bolivia & \\
\hline \multirow{5}{*}{ Nasua nasua } & MACN-MA 49402 & $\mathrm{~m} 1$ & 우 & Bolivia & \multirow{5}{*}{$\begin{array}{c}\text { Omnivore } \\
\text { (Kays, 2009) }\end{array}$} \\
\hline & MACN-MA 49415 & $\mathrm{~m} 1$ & $\hat{0}$ & Misiones, Argentina & \\
\hline & MACN-MA 49457 & $\mathrm{~m} 1$ & $\hat{0}$ & Misiones, Argentina & \\
\hline & MACN-MA 50.77 & $\mathrm{~m} 1$ & 우 & Misiones, Argentina & \\
\hline & MACN-MA 50535 & $\mathrm{~m} 1$ & $\hat{0}$ & Misiones, Argentina & \\
\hline \multirow{6}{*}{ Procyon cancrivorus } & MACN-MA 13816 & $\mathrm{~m} 1$ & - & Jujuy, Argentina & \multirow{6}{*}{$\begin{array}{c}\text { Omnivore } \\
\text { (Kays, 2009) }\end{array}$} \\
\hline & MACN-MA 16190 & $\mathrm{~m} 1$ & - & Tucumán, Argentina & \\
\hline & MACN-MA 17116 & $\mathrm{~m} 1$ & - & Santa Fe, Argentina & \\
\hline & MACN-MA 32254 & $\mathrm{~m} 1$ & 우 & Corrientes, Argentina & \\
\hline & MACN-MA 33.7 & $\mathrm{~m} 1$ & 우 & Jujuy, Argentina & \\
\hline & MACN-MA 41109 & $\mathrm{~m} 1$ & q & $\begin{array}{c}\text { San Javier, Santa Fe, } \\
\text { Argentina }\end{array}$ & \\
\hline \multirow{2}{*}{ Procyon lotor } & MLP-MA 1005 & $\mathrm{~m} 1$ & - & - & \multirow{2}{*}{$\begin{array}{c}\text { Omnivore } \\
\text { (Kays, 2009) }\end{array}$} \\
\hline & MLP-PV S/N & $\mathrm{m} 1$ & 우 & Massachusetts, USA & \\
\hline
\end{tabular}




\begin{tabular}{|c|c|c|c|c|c|c|}
\hline & Species & Collection number & Digitized molar & Sex & Provenance & $\begin{array}{c}\text { Diet } \\
\text { (reference) }\end{array}$ \\
\hline \multicolumn{7}{|c|}{ Metatheria } \\
\hline \multicolumn{7}{|c|}{ |Dasyuromorphia } \\
\hline \multicolumn{7}{|c|}{ Dasyuridae } \\
\hline \multicolumn{7}{|c|}{ Dasyurinae } \\
\hline & Dasyurus geoffroii & FMNH 35329 & $\mathrm{~m} 4$ & ㅇ & Australia & $\begin{array}{c}\text { Mesocarnivore } \\
\text { (Baker, 2015) }\end{array}$ \\
\hline \multicolumn{7}{|c|}{ Thylacinidae } \\
\hline & Thylacinus cynocephalus & FMNH 81522 & $\mathrm{~m} 4$ & - & Tasmania & Hypercarnivore (Helgen \& Veatch, 2015) \\
\hline \multicolumn{7}{|c|}{ Didelphimorphia } \\
\hline \multicolumn{7}{|c|}{ Didelphidae } \\
\hline \multicolumn{7}{|c|}{ Didelphinae } \\
\hline \multirow{6}{*}{\multicolumn{2}{|c|}{ Didelphis albiventris }} & MACN-MA 13139 & $\mathrm{~m} 4$ & q & $\begin{array}{c}\text { Concordia, Entre Ríos, } \\
\text { Argentina }\end{array}$ & \multirow{6}{*}{$\begin{array}{c}\text { Omnivore } \\
\text { (Vieira \& Astúa de Moraes, 2003) }\end{array}$} \\
\hline & & MACN-MA 24149 & $\mathrm{~m} 4$ & $\hat{0}$ & Bs. As., Argentina & \\
\hline & & MACN-MA 24150 & $\mathrm{~m} 4$ & - & Corrientes, Argentina & \\
\hline & & MACN-MA 24169 & $\mathrm{~m} 4$ & $\hat{0}$ & $\begin{array}{c}\text { Concordia, Entre Ríos, } \\
\text { Argentina }\end{array}$ & \\
\hline & & MACN-MA 49.49 & $\mathrm{~m} 4$ & - & Corrientes, Argentina & \\
\hline & & MACN-MA 49.51 & $\mathrm{~m} 4$ & 0 & Corrientes, Argentina & \\
\hline \multirow{6}{*}{\multicolumn{2}{|c|}{ Lutreolina crassicaudata }} & MACN-MA 13265 & $\mathrm{~m} 4$ & $\delta$ & Bs. As., Argentina & \multirow{6}{*}{$\begin{array}{c}\text { Mesocarnivore } \\
\text { (Vieira \& Astúa de Moraes, 2003) }\end{array}$} \\
\hline & & MACN-MA 24110 & $\mathrm{~m} 4$ & $0^{\pi}$ & Formosa, Argentina & \\
\hline & & MACN-MA 24111 & $\mathrm{~m} 4$ & - & Corrientes, Argentina & \\
\hline & & MACN-MA 24112 & $\mathrm{~m} 4$ & $\hat{0}$ & Corrientes, Argentina & \\
\hline & & MACN-MA 24780 & $\mathrm{~m} 4$ & - & Corrientes, Argentina & \\
\hline & & MACN-MA 50477 & $\mathrm{~m} 4$ & $\hat{0}$ & Bs. As., Argentina & \\
\hline
\end{tabular}




\section{Institutional abbreviations}

AMNH, American Museum of Natural History, New York; FMNH, Field Museum of Natural History, Chicago; MLP, Museo de La Plata, La Plata; MACN, Museo Argentino de Ciencias Naturales "Bernardino Rivadavia", Ciudad Autónoma de Buenos Aires; MNHN, Muséum National d'Histoire Naturelle, Paris.

\section{References}

Baker, A.M. 2015. Family Dasyuridae (Carnivorous marsupials). In: Wilson, D.E. and R.A. Mittermeier (Eds.), Handbook of the Mammals of the World. Vol. 5. Monotremes and Marsupials, Lynx Edicions, Barcelona, pp. 232-348.

Dragoo, J.W. 2009. Family Mephitidae (Skunks). In: Wilson, D.E. and R.A. Mittermeier (Eds.), Handbook of the Mammals of the World. Vol. 1. Carnivores, Lynx Edicions, Barcelona, pp. 532-563.

Garshelis, D.L. 2009. Family Ursidae (Bears). In: Wilson, D.E. and R.A. Mittermeier (Eds.), Handbook of the Mammals of the World. Vol. 1. Carnivores, Lynx Edicions, Barcelona, pp. 448-497.

Helgen, K.M. and Veatch, E.G. 2015. Recent extinct australian marsupials and monotremes. In: Wilson, D.E. and R.A. Mittermeier (Eds.), Handbook of the Mammals of the World. Vol. 5. Monotremes and Marsupials, Lynx Edicions, Barcelona, pp. 17-31.

Holekamp, K.E. and Kolowski, J.M. 2009. Family Hyaenidae (Hyenas). In: Wilson, D.E. and R.A. Mittermeier (Eds.), Handbook of the Mammals of the World. Vol. 1. Carnivores, Lynx Edicions, Barcelona, pp. 234-261.

Kays, R. 2009. Family Procyonidae (Raccons). In: Wilson, D.E. and R.A. Mittermeier (Eds.), Handbook of the Mammals of the World. Vol. 1. Carnivores, Lynx Edicions, Barcelona, pp. 504-531.

Kruuk, H. 2006. Otters: Ecology Behaviour and Conservation. Oxford University Press, New York.

Larivière, S. and Jennings, A.P. 2009. Family Mustelidae (Weasels and relatives). In: Wilson, D.E. and R.A. Mittermeier (Eds.), Handbook of the Mammals of the World. Vol. 1. Carnivores, Lynx Edicions, Barcelona, pp. 564-656.

Padial, J.M., Avila, E. and Sanchez, J.M. 2002. Feeding habits and overlap among red fox (Vulpes vulpes) and stone marten (Martes foina) in two Mediterranean mountain habitats. Mammalian Biology 67: 137-146.

Rosalino, L.M. and Santos-Reis, M. 2009. Fruit consumption by carnivores in Mediterranean Europe. Mammal Review 39: 67-78. 
Sillero-Zubiri, C. 2009. Family Canidae (Dogs). In: Wilson, D.E. and R.A. Mittermeier (Eds.), Handbook of the Mammals of the World. Vol. 1. Carnivores, Lynx Edicions, Barcelona, pp. 352-447.

Sunquist, M.E. and Sunquist, F.C. 2009. Family Felidae (Cats). In: Wilson, D.E. and R.A. Mittermeier (Eds.), Handbook of the Mammals of the World. Vol. 1. Carnivores, Lynx Edicions, Barcelona, pp. 54-169.

Torre, I., Ballesteros, T. and Degollada, A. 2003. Changes in the diet of the genet (Genetta genetta Linnaeus, 1758) in relation to small mammal-prey availability: possible choice of the bank vole? Galemys 15: 25-36.

Vieira, E.M. and Astúa de Moraes, D. 2003. Carnivory and insectivory in Neotropical marsupials. In: Jones, M.E., C.R. Dickman and M. Archer (Eds.), Predators with pouches, CSIRO Publishing, Collingwood, pp. 271-284. 


\title{
The scope of traditional and geometric morphometrics for inferences of diet in carnivorous fossil mammals
}

\author{
Sergio D. Tarquini ${ }^{1 *}$, M. Amelia Chemisquy ${ }^{1,2}$, Sandrine Ladevèze ${ }^{3}$, and
} Francisco J. Prevosti ${ }^{1,2}$

1- Centro Regional de Investigaciones Científicas y Transferencia Tecnológica de La Rioja (CRILAR - Provincia de La Rioja, UNLaR, SEGEMAR, UNCa, CONICET). Entre Ríos y Mendoza s/n (5301), Anillaco, Argentina. starquini92@gmail.com; amelych80@gmail.com; protocyon@hotmail.com

2- Departamento de Ciencias Exactas, Físicas y Naturales, Universidad Nacional de la Rioja (UNLaR). Av. Luis M. de la Fuente s/n (5300), La Rioja, Argentina.

3- Centre de Recherche en Paléontologie - Paris (CR2P - CNRS, MNHN, Sorbonne Université). 8 rue Buffon CP38 (75005), Paris, France. sandrine.ladeveze@mnhn.fr 
SUPPLEMENTARY ONLINE INFORMATION 2. Confusion matrices of the different Discriminant Analyses using the scores of the classic indices and the bg-PCs. PCPR $=$ Percentage of Correct Posterior Reclassification (global percentage shown in bold).

\begin{tabular}{|c|c|c|c|c|c|c|}
\hline \multicolumn{7}{|c|}{ Linear Discriminant Analysis } \\
\hline \multicolumn{7}{|c|}{ All (3) indices } \\
\hline & Herbivore & Hypercarnivore & Mesocarnivore & Omnivore & Piscivore & PCPR \\
\hline Herbivore & 3 & 0 & 0 & 2 & 1 & 50.00 \\
\hline Hypercarnivore & 0 & 70 & 33 & 1 & 1 & 66.67 \\
\hline Mesocarnivore & 0 & 1 & 23 & 6 & 4 & 67.65 \\
\hline Omnivore & 17 & 0 & 26 & 13 & 15 & 18.31 \\
\hline Piscivore & 1 & 0 & 1 & 5 & 6 & 46.15 \\
\hline \%Error & 85.71 & 1.41 & 72.29 & 51.85 & 77.78 & 50.22 \\
\hline \multicolumn{7}{|c|}{$\boldsymbol{R G A}$} \\
\hline Herbivore & 3 & 0 & 0 & 1 & 2 & 50.00 \\
\hline Hypercarnivore & 0 & 72 & 31 & 2 & 0 & 68.57 \\
\hline Mesocarnivore & 0 & 1 & 26 & 6 & 1 & 76.47 \\
\hline Omnivore & 21 & 0 & 31 & 12 & 7 & 16.90 \\
\hline Piscivore & 1 & 0 & 1 & 8 & 3 & 23.08 \\
\hline \%Error & 88.00 & 1.37 & 70.79 & 58.62 & 76.92 & 50.66 \\
\hline \multicolumn{7}{|c|}{$A I$} \\
\hline Herbivore & 3 & 2 & 0 & 1 & 0 & 50.00 \\
\hline Hypercarnivore & 1 & 90 & 12 & 2 & 0 & 85.71 \\
\hline Mesocarnivore & 7 & 14 & 8 & 0 & 5 & 23.53 \\
\hline Omnivore & 22 & 9 & 28 & 3 & 9 & 4.23 \\
\hline Piscivore & 4 & 0 & 4 & 2 & 3 & 23.08 \\
\hline \%Error & 91.89 & 21.74 & 84.62 & 62.50 & 82.35 & 46.72 \\
\hline \multicolumn{7}{|c|}{ Angle $\alpha$} \\
\hline Herbivore & 4 & 0 & 0 & 0 & 2 & 66.67 \\
\hline Hypercarnivore & 4 & 70 & 20 & 9 & 2 & 66.67 \\
\hline Mesocarnivore & 1 & 3 & 24 & 5 & 1 & 70.59 \\
\hline Omnivore & 21 & 0 & 30 & 15 & 5 & 21.13 \\
\hline Piscivore & 4 & 0 & 0 & 5 & 4 & 30.77 \\
\hline \%Error & 88.24 & 4.11 & 67.57 & 55.88 & 71.43 & 51.09 \\
\hline
\end{tabular}




\begin{tabular}{|c|c|c|c|c|c|c|}
\hline \multicolumn{7}{|c|}{ Linear Discriminant Analysis } \\
\hline & \multicolumn{5}{|c|}{$A l l(4) b g-P C s$} & \multirow[b]{2}{*}{$P C P R$} \\
\hline & Herbivore & Hypercarnivore & Mesocarnivore & Omnivore & Piscivore & \\
\hline Herbivore & 5 & 0 & 0 & 1 & 0 & 83.33 \\
\hline Hypercarnivore & 0 & 93 & 6 & 5 & 1 & 88.57 \\
\hline Mesocarnivore & 0 & 0 & 28 & 3 & 3 & 82.35 \\
\hline Omnivore & 17 & 0 & 8 & 40 & 6 & 56.34 \\
\hline Piscivore & 0 & 0 & 0 & 0 & 13 & 100.00 \\
\hline \%Error & 77.27 & 0.00 & 33.33 & 18.37 & 43.48 & 78.17 \\
\hline \multicolumn{7}{|c|}{$3 \mathrm{bg}-\mathrm{PCs}$} \\
\hline Herbivore & 5 & 0 & 0 & 1 & 0 & 83.33 \\
\hline Hypercarnivore & 0 & 91 & 7 & 5 & 2 & 86.67 \\
\hline Mesocarnivore & 0 & 4 & 23 & 6 & 1 & 67.65 \\
\hline Omnivore & 20 & 0 & 17 & 27 & 7 & 38.03 \\
\hline Piscivore & 0 & 0 & 0 & 0 & 13 & 100.00 \\
\hline \%Error & 80.00 & 4.21 & 51.06 & 30.77 & 43.48 & 69.43 \\
\hline \multicolumn{7}{|c|}{ bg-PC1 } \\
\hline Herbivore & 3 & 0 & 0 & 3 & 0 & 50.00 \\
\hline Hypercarnivore & 0 & 80 & 21 & 4 & 0 & 76.19 \\
\hline Mesocarnivore & 0 & 2 & 27 & 0 & 5 & 79.41 \\
\hline Omnivore & 24 & 0 & 13 & 8 & 26 & 11.27 \\
\hline Piscivore & 0 & 0 & 0 & 2 & 11 & 84.62 \\
\hline \%Error & 88.89 & 2.44 & 55.74 & 52.94 & 73.81 & 56.33 \\
\hline
\end{tabular}




\begin{tabular}{|c|c|c|c|c|c|c|}
\hline \multicolumn{7}{|c|}{ Quadratic Discriminant Analysis } \\
\hline & \multicolumn{5}{|c|}{ All (3) indices } & \multirow[b]{2}{*}{$P C P R$} \\
\hline & Herbivore & Hypercarnivore & Mesocarnivore & Omnivore & Piscivore & \\
\hline Herbivore & 3 & 0 & 0 & 3 & 0 & 50.00 \\
\hline Hypercarnivore & 1 & 77 & 25 & 0 & 2 & 73.33 \\
\hline Mesocarnivore & 0 & 3 & 28 & 2 & 1 & 82.36 \\
\hline Omnivore & 10 & 0 & 34 & 20 & 7 & 28.17 \\
\hline Piscivore & 1 & 0 & 0 & 2 & 10 & 76.92 \\
\hline \%Error & 80.00 & 3.75 & 67.82 & 25.93 & 50.00 & 60.26 \\
\hline \multicolumn{7}{|c|}{$\boldsymbol{R} \boldsymbol{G A}$} \\
\hline Herbivore & 3 & 0 & 0 & 1 & 2 & 50.00 \\
\hline Hypercarnivore & 0 & 73 & 30 & 0 & 2 & 69.52 \\
\hline Mesocarnivore & 0 & 2 & 26 & 0 & 6 & 76.47 \\
\hline Omnivore & 19 & 0 & 33 & 3 & 16 & 4.23 \\
\hline Piscivore & 0 & 0 & 1 & 1 & 11 & 84.62 \\
\hline \%Error & 86.36 & 2.67 & 71.11 & 40.00 & 70.27 & 50.66 \\
\hline \multicolumn{7}{|c|}{$\boldsymbol{A I}$} \\
\hline Herbivore & 3 & 2 & 0 & 0 & 1 & 50.00 \\
\hline Hypercarnivore & 0 & 92 & 10 & 0 & 3 & 87.62 \\
\hline Mesocarnivore & 0 & 16 & 6 & 1 & 11 & 17.65 \\
\hline Omnivore & 9 & 10 & 23 & 10 & 19 & 14.08 \\
\hline Piscivore & 0 & 0 & 2 & 0 & 11 & 84.62 \\
\hline \%Error & 75.00 & 23.33 & 85.37 & 9.09 & 75.56 & $\mathbf{5 3 . 2 8}$ \\
\hline \multicolumn{7}{|c|}{ Angle $\alpha$} \\
\hline Herbivore & 3 & 0 & 0 & 1 & 2 & 50.00 \\
\hline Hypercarnivore & 4 & 70 & 25 & 1 & 5 & 66.67 \\
\hline Mesocarnivore & 1 & 3 & 26 & 2 & 2 & 76.47 \\
\hline Omnivore & 21 & 0 & 32 & 4 & 14 & 5.63 \\
\hline Piscivore & 5 & 0 & 1 & 2 & 5 & 38.46 \\
\hline \%Error & 91.18 & 4.11 & 69.05 & 60.00 & 82.14 & 47.16 \\
\hline
\end{tabular}




\begin{tabular}{|c|c|c|c|c|c|c|}
\hline \multicolumn{7}{|c|}{ Quadratic Discriminant Analysis } \\
\hline & \multicolumn{5}{|c|}{$A l l(4) b g-P C s$} & \multirow[b]{2}{*}{$P C P R$} \\
\hline & Herbivore & Hypercarnivore & Mesocarnivore & Omnivore & Piscivore & \\
\hline Herbivore & 2 & 0 & 0 & 4 & 0 & 33.33 \\
\hline Hypercarnivore & 0 & 93 & 8 & 4 & 0 & 88.57 \\
\hline Mesocarnivore & 0 & 0 & 28 & 6 & 0 & 82.35 \\
\hline Omnivore & 9 & 1 & 14 & 47 & 0 & 66.20 \\
\hline Piscivore & 0 & 0 & 0 & 0 & 13 & 100.00 \\
\hline \%Error & 81.81 & 1.06 & 44.00 & 22.95 & 0.00 & 79.91 \\
\hline \multicolumn{7}{|c|}{$3 \mathrm{bg}-\mathrm{PCs}$} \\
\hline Herbivore & 4 & 0 & 0 & 2 & 0 & 66.67 \\
\hline Hypercarnivore & 0 & 88 & 13 & 4 & 0 & 83.81 \\
\hline Mesocarnivore & 0 & 4 & 25 & 5 & 0 & 73.53 \\
\hline Omnivore & 13 & 0 & 22 & 36 & 0 & 50.70 \\
\hline Piscivore & 0 & 0 & 0 & 0 & 13 & 100.00 \\
\hline \%Error & 76.47 & 4.35 & 58.33 & 23.40 & 0.00 & 72.49 \\
\hline \multicolumn{7}{|c|}{ bg-PC1 } \\
\hline Herbivore & 3 & 0 & 0 & 3 & 0 & 50.00 \\
\hline Hypercarnivore & 0 & 88 & 13 & 4 & 0 & 83.81 \\
\hline Mesocarnivore & 0 & 3 & 26 & 0 & 5 & 76.47 \\
\hline Omnivore & 25 & 0 & 16 & 5 & 25 & 7.04 \\
\hline Piscivore & 0 & 0 & 1 & 2 & 10 & 76.92 \\
\hline \%Error & 89.29 & 3.30 & 53.57 & 64.29 & 75.00 & 57.64 \\
\hline
\end{tabular}




\begin{tabular}{|c|c|c|c|c|c|c|}
\hline \multicolumn{7}{|c|}{ Weighted Random Forests } \\
\hline & \multicolumn{5}{|c|}{ All (3) indices } & \multirow[b]{2}{*}{$P C P R$} \\
\hline & Herbivore & Hypercarnivore & Mesocarnivore & Omnivore & Piscivore & \\
\hline Herbivore & 1 & 1 & 1 & 3 & 0 & 16.67 \\
\hline Hypercarnivore & 0 & 93 & 9 & 3 & 0 & 88.57 \\
\hline Mesocarnivore & 0 & 12 & 14 & 8 & 0 & 41.18 \\
\hline Omnivore & 0 & 2 & 3 & 62 & 4 & 87.32 \\
\hline Piscivore & 0 & 0 & 0 & 9 & 4 & 30.77 \\
\hline \%Error & 0.00 & 13.89 & 48.15 & 27.06 & 50.00 & 75.98 \\
\hline \multicolumn{7}{|c|}{$\boldsymbol{R} \boldsymbol{G A}$} \\
\hline Herbivore & 2 & 0 & 0 & 3 & 1 & 33.33 \\
\hline Hypercarnivore & 0 & 85 & 11 & 8 & 1 & 80.95 \\
\hline Mesocarnivore & 1 & 12 & 8 & 12 & 1 & 23.53 \\
\hline Omnivore & 1 & 9 & 9 & 44 & 8 & 61.97 \\
\hline Piscivore & 1 & 2 & 1 & 6 & 3 & 23.08 \\
\hline \%Error & 60.00 & 21.30 & 62.07 & 39.73 & 78.57 & 62.01 \\
\hline \multicolumn{7}{|c|}{$A I$} \\
\hline Herbivore & 0 & 2 & 1 & 3 & 0 & 0.00 \\
\hline Hypercarnivore & 2 & 87 & 10 & 4 & 2 & 82.86 \\
\hline Mesocarnivore & 0 & 12 & 10 & 11 & 1 & 29.41 \\
\hline Omnivore & 2 & 3 & 11 & 49 & 6 & 69.01 \\
\hline Piscivore & 0 & 1 & 1 & 8 & 3 & 23.08 \\
\hline \%Error & 100.00 & 17.14 & 69.70 & 34.67 & 75.00 & 65.07 \\
\hline \multicolumn{7}{|c|}{ Angle $\alpha$} \\
\hline Herbivore & 0 & 1 & 0 & 2 & 3 & 0.00 \\
\hline Hypercarnivore & 2 & 75 & 14 & 13 & 1 & 71.43 \\
\hline Mesocarnivore & 0 & 12 & 9 & 12 & 1 & 26.47 \\
\hline Omnivore & 3 & 16 & 11 & 32 & 9 & 45.07 \\
\hline Piscivore & 2 & 3 & 1 & 7 & 0 & 0.00 \\
\hline \%Error & 100.00 & 29.91 & 74.29 & 51.52 & 100.00 & 50.66 \\
\hline
\end{tabular}




\begin{tabular}{|c|c|c|c|c|c|c|}
\hline \multicolumn{7}{|c|}{ Weighted Random Forests } \\
\hline & \multicolumn{5}{|c|}{$A l l(4) b g-P C s$} & \multirow[b]{2}{*}{$P C P R$} \\
\hline & Herbivore & Hypercarnivore & Mesocarnivore & Omnivore & Piscivore & \\
\hline Herbivore & 3 & 0 & 0 & 3 & 0 & 50.00 \\
\hline Hypercarnivore & 0 & 97 & 2 & 6 & 0 & 92.38 \\
\hline Mesocarnivore & 0 & 1 & 29 & 4 & 0 & 85.29 \\
\hline Omnivore & 1 & 1 & 5 & 64 & 0 & 90.14 \\
\hline Piscivore & 0 & 0 & 0 & 0 & 13 & 100.00 \\
\hline \%Error & 25.00 & 2.02 & 19.44 & 27.66 & 0.00 & 89.96 \\
\hline \multicolumn{7}{|c|}{$3 \mathrm{bg}-\mathrm{PCs}$} \\
\hline Herbivore & 1 & 0 & 0 & 5 & 0 & 16.67 \\
\hline Hypercarnivore & 0 & 99 & 3 & 3 & 0 & 94.29 \\
\hline Mesocarnivore & 0 & 4 & 21 & 9 & 0 & 61.76 \\
\hline Omnivore & 1 & 2 & 6 & 62 & 0 & 87.32 \\
\hline Piscivore & 0 & 0 & 0 & 0 & 13 & 100.00 \\
\hline \%Error & 50.00 & 5.71 & 30.00 & 21.52 & 0.00 & 85.59 \\
\hline \multicolumn{7}{|c|}{$b g-P C 1$} \\
\hline Herbivore & 5 & 0 & 0 & 1 & 0 & 83.33 \\
\hline Hypercarnivore & 0 & 92 & 10 & 2 & 1 & 87.62 \\
\hline Mesocarnivore & 0 & 9 & 17 & 5 & 3 & 50.00 \\
\hline Omnivore & 2 & 3 & 7 & 52 & 7 & 73.24 \\
\hline Piscivore & 0 & 1 & 2 & 5 & 5 & 38.46 \\
\hline \%Error & 28.57 & 12.38 & 52.78 & 20.00 & 68.75 & 74.67 \\
\hline
\end{tabular}




\title{
The scope of traditional and geometric morphometrics for inferences of diet in carnivorous fossil mammals
}

\author{
Sergio D. Tarquini ${ }^{1 *}$, M. Amelia Chemisquy ${ }^{1,2}$, Sandrine Ladevèze ${ }^{3}$, and
} Francisco J. Prevosti ${ }^{1,2}$

1- Centro Regional de Investigaciones Científicas y Transferencia Tecnológica de La Rioja (CRILAR - Provincia de La Rioja, UNLaR, SEGEMAR, UNCa, CONICET). Entre Ríos y Mendoza s/n (5301), Anillaco, Argentina. starquini92@gmail.com; amelych80@gmail.com; protocyon@hotmail.com

2- Departamento de Ciencias Exactas, Físicas y Naturales, Universidad Nacional de la Rioja (UNLaR). Av. Luis M. de la Fuente s/n (5300), La Rioja, Argentina.

3- Centre de Recherche en Paléontologie - Paris (CR2P - CNRS, MNHN, Sorbonne Université). 8 rue Buffon CP38 (75005), Paris, France. sandrine.ladeveze@mnhn.fr 
SUPPLEMENTARY ONLine INFORMation 3. Confusion matrices of the Discriminant Analyses using the scores of the classic indices and the bg-PCs within Canidae. PCPR = Percentage of Correct Posterior Reclassification (global percentage shown in bold).

\begin{tabular}{|c|c|c|c|c|}
\hline \multicolumn{5}{|c|}{ Linear Discriminant Analysis } \\
\hline \multicolumn{5}{|c|}{$A l l(2) b g-P C s$} \\
\hline & Hypercarnivore & Mesocarnivore & Omnivore & $P C P R$ \\
\hline Hypercarnivore & 8 & 1 & 0 & 88.89 \\
\hline Mesocarnivore & 0 & 15 & 0 & 100.00 \\
\hline Omnivore & 0 & 4 & 24 & 85.71 \\
\hline \%Error & 0.00 & 25.00 & 0.00 & 90.38 \\
\hline \multicolumn{5}{|c|}{ All (3) índices } \\
\hline Hypercarnivore & 5 & 4 & 0 & 55.56 \\
\hline Mesocarnivore & 6 & 9 & 0 & 55.56 \\
\hline Omnivore & 3 & 2 & 23 & 82.14 \\
\hline \%Error & 64.29 & 40.00 & 0.00 & 71.15 \\
\hline \multicolumn{5}{|c|}{ Bg-PC1 } \\
\hline Hypercarnivore & 8 & 1 & 0 & 88.89 \\
\hline Mesocarnivore & 0 & 14 & 1 & 93.33 \\
\hline Omnivore & 0 & 5 & 23 & 82.14 \\
\hline \%Error & 0.00 & 30.00 & 4.17 & 86.54 \\
\hline \multicolumn{5}{|c|}{$R G A$} \\
\hline Hypercarnivore & 0 & 9 & 0 & 0.00 \\
\hline Mesocarnivore & 11 & 2 & 2 & 13.33 \\
\hline Omnivore & 4 & 0 & 24 & 85.71 \\
\hline \%Error & 100.00 & 81.82 & 7.69 & 50.00 \\
\hline \multicolumn{5}{|c|}{$A I$} \\
\hline Hypercarnivore & 5 & 4 & 0 & 55.56 \\
\hline Mesocarnivore & 6 & 5 & 4 & 33.33 \\
\hline Omnivore & 1 & 7 & 20 & 71.43 \\
\hline \%Error & 58.33 & 68.75 & 16.67 & 57.69 \\
\hline \multicolumn{5}{|c|}{ Angle $\alpha$} \\
\hline Hypercarnivore & 0 & 4 & 5 & 0.00 \\
\hline Mesocarnivore & 3 & 8 & 4 & 53.33 \\
\hline Omnivore & 3 & 14 & 11 & 39.29 \\
\hline \%Error & 100.00 & 77.78 & 45.00 & 36.54 \\
\hline
\end{tabular}




\begin{tabular}{|c|c|c|c|c|}
\hline \multicolumn{5}{|c|}{ Quadratic Discriminant Analysis } \\
\hline \multicolumn{5}{|c|}{$A l l(2) b g-P C s$} \\
\hline & Hypercarnivore & Mesocarnivore & Omnivore & $P C P R$ \\
\hline Hypercarnivore & 8 & 1 & 0 & 88.89 \\
\hline Mesocarnivore & 1 & 14 & 0 & 93.33 \\
\hline Omnivore & 0 & 3 & 25 & 89.29 \\
\hline \%Error & 11.11 & 22.22 & 0.00 & 90.38 \\
\hline \multicolumn{5}{|c|}{ All (3) indices } \\
\hline Hypercarnivore & 4 & 5 & 0 & 44.44 \\
\hline Mesocarnivore & 4 & 9 & 2 & 60.00 \\
\hline Omnivore & 1 & 6 & 21 & 75.00 \\
\hline \%Error & 55.56 & 55.00 & 8.70 & 65.38 \\
\hline \multicolumn{5}{|c|}{ Bg-PC1 } \\
\hline Hypercarnivore & 8 & 1 & 0 & 88.89 \\
\hline Mesocarnivore & 1 & 13 & 1 & 86.67 \\
\hline Omnivore & 0 & 5 & 23 & 82.14 \\
\hline \%Error & 11.11 & 33.33 & 4.17 & 84.62 \\
\hline \multicolumn{5}{|c|}{$R G A$} \\
\hline Hypercarnivore & 7 & 2 & 0 & 77.78 \\
\hline Mesocarnivore & 10 & 3 & 2 & 20.00 \\
\hline Omnivore & 2 & 2 & 24 & 85.71 \\
\hline \%Error & 63.16 & 57.14 & 7.69 & 65.38 \\
\hline \multicolumn{5}{|c|}{$A I$} \\
\hline Hypercarnivore & 5 & 4 & 0 & 55.56 \\
\hline Mesocarnivore & 6 & 5 & 4 & 33.33 \\
\hline Omnivore & 1 & 7 & 20 & 71.43 \\
\hline \%Error & 58.33 & 68.75 & 83.33 & 57.69 \\
\hline \multicolumn{5}{|c|}{ Angle $\alpha$} \\
\hline Hypercarnivore & 2 & 3 & 4 & 22.22 \\
\hline Mesocarnivore & 2 & 7 & 6 & 46.67 \\
\hline Omnivore & 3 & 17 & 8 & 28.57 \\
\hline \%Error & 71.43 & 74.07 & 55.56 & 32.69 \\
\hline
\end{tabular}




\begin{tabular}{|c|c|c|c|c|}
\hline \multicolumn{5}{|c|}{ Weighted Random Forests } \\
\hline \multicolumn{5}{|c|}{$A l l(2) b g-P C s$} \\
\hline & Hypercarnivore & Mesocarnivore & Omnivore & $P C P R$ \\
\hline Hypercarnivore & 8 & 1 & 0 & 88.89 \\
\hline Mesocarnivore & 0 & 14 & 1 & 93.33 \\
\hline Omnivore & 0 & 2 & 26 & 92.86 \\
\hline \%Error & 0.00 & 17.65 & 3.70 & 92.31 \\
\hline \multicolumn{5}{|c|}{ All (3) indices } \\
\hline Hypercarnivore & 2 & 7 & 0 & 22.22 \\
\hline Mesocarnivore & 4 & 8 & 3 & 53.33 \\
\hline Omnivore & 0 & 2 & 26 & 92.86 \\
\hline \%Error & 66.67 & 52.94 & 10.34 & 69.23 \\
\hline \multicolumn{5}{|c|}{$B g-P C 1$} \\
\hline Hypercarnivore & 8 & 1 & 0 & 88.89 \\
\hline Mesocarnivore & 1 & 9 & 5 & 60.00 \\
\hline Omnivore & 0 & 6 & 22 & 78.57 \\
\hline \%Error & 11.11 & 43.75 & 18.52 & 75.00 \\
\hline \multicolumn{5}{|c|}{$R G A$} \\
\hline Hypercarnivore & 1 & 7 & 1 & 11.11 \\
\hline Mesocarnivore & 6 & 6 & 3 & 40.00 \\
\hline Omnivore & 0 & 3 & 25 & 89.29 \\
\hline \%Error & 85.71 & 62.50 & 13.79 & 61.54 \\
\hline \multicolumn{5}{|c|}{$A I$} \\
\hline Hypercarnivore & 6 & 2 & 1 & 66.67 \\
\hline Mesocarnivore & 4 & 6 & 5 & 40.00 \\
\hline Omnivore & 1 & 4 & 23 & 82.14 \\
\hline \%Error & 45.45 & 50.00 & 20.69 & 67.31 \\
\hline \multicolumn{5}{|c|}{ Angle $\alpha$} \\
\hline Hypercarnivore & 1 & 2 & 6 & 11.11 \\
\hline Mesocarnivore & 2 & 4 & 9 & 26.67 \\
\hline Omnivore & 6 & 5 & 17 & 60.71 \\
\hline \%Error & 88.89 & 63.64 & 46.88 & 42.31 \\
\hline
\end{tabular}




\title{
The scope of traditional and geometric morphometrics for inferences of diet in carnivorous fossil mammals
}

\author{
Sergio D. Tarquini ${ }^{1 *}$, M. Amelia Chemisquy ${ }^{1,2}$, Sandrine Ladevèze ${ }^{3}$, and
} Francisco J. Prevosti ${ }^{1,2}$

1- Centro Regional de Investigaciones Científicas y Transferencia Tecnológica de La Rioja (CRILAR - Provincia de La Rioja, UNLaR, SEGEMAR, UNCa, CONICET). Entre Ríos y Mendoza s/n (5301), Anillaco, Argentina. starquini92@gmail.com; amelych80@gmail.com; protocyon@hotmail.com

2- Departamento de Ciencias Exactas, Físicas y Naturales, Universidad Nacional de la Rioja (UNLaR). Av. Luis M. de la Fuente s/n (5300), La Rioja, Argentina.

3- Centre de Recherche en Paléontologie - Paris (CR2P - CNRS, MNHN, Sorbonne Université). 8 rue Buffon CP38 (75005), Paris, France. sandrine.ladeveze@mnhn.fr 
SUPPLEMENTARY ONLINE INFORMATION 4. Differences in classifications if the RGA is averaged by species or not.

The RGA values used in this study correspond to measurements taken by calliper (Prevosti, 2006). We compared the use of the average value of the RGA per species, versus the use of the observed variation (i.e., including the value of each specimen separately). In the first case, we averaged the RGA per species, obtaining a single value per species. Under this example, the diets could be classified with a series of logical rules: e.g., a taxon can be considered hypercarnivorous when the RGA index is lower than 0.45; insectivore when the RGA index is larger than 1. Although the limit between omnivores and mesocarnivores is ambiguous and it is usually determined arbitrarily.

\section{RGA AVERAGED}

$\begin{array}{cccc}\text { Species } & \text { RGA } & \text { Diet } & \begin{array}{c}\text { Classification based on the } \\ \text { limits established by the RGA }\end{array} \\ \text { Cuos alpinus } & 0.396 & \text { Hypercarnivore } & \\ \text { Lycaon pictus } & 0.427 & \text { Hypercarnivore } & \text { Hypercarnivore } \\ \text { Canis lupus } & 0.440 & \text { Hypercarnivore } & \\ \text { Speothos venaticus } & 0.447 & \text { Hypercarnivore } & \\ \text { Canis latrans } & 0.468 & \text { Mesocarnivore } & \text { Mesocarnivore } \\ \text { Vulpes lagopus } & 0.472 & \text { Mesocarnivore } & \\ \text { Cerdocyon thous } & 0.483 & \text { Omnivore } & \\ \text { Lycalopex culpeus } & 0.501 & \text { Mesocarnivore } & \\ \text { Chrysocyon brachyurus } & 0.510 & \text { Omnivore } & \\ \text { Vulpes vulpes } & 0.537 & \text { Mesocarnivore } & \text { Omnivore / } \\ \text { Lycalopex gymnocercus } & 0.540 & \text { Omnivore } & \text { Mesocarnivore } \\ \text { Canis aureus } & 0.570 & \text { Mesocarnivore } & \\ \text { Lycalopex griseus } & 0.573 & \text { Omnivore } & \\ \text { Vulpes zerda } & 0.596 & \text { Omnivore } & \text { Omnivore } \\ \text { Urocyon cinereoargenteus } & 0.630 & \text { Omnivore } & \\ \text { Lycalopex vetus } & 0.676 & \text { Omnivore } & \text { Insectivore } \\ \text { Otocyon megalotis } & 1.092 & \text { Insectivore } & \end{array}$

In the second case, we used the intraspecific variation including the maximum and minimum values for each species. Considering these values, the overlap between the diet categories is much greater. The limits between hypercarnivores and mesocarnivores, hypercarnivores and omnivores, and omnivores and mesocarnivores, are ambiguous. 


\section{MAXIMUM AND MINIMUM RGA FOR EACH SPECIES}

\begin{tabular}{|c|c|c|c|}
\hline Species & RGA & Diet & $\begin{array}{l}\text { Classification based on the } \\
\text { limits established by the RGA }\end{array}$ \\
\hline Cuon alpinus (max) & 0.38315075 & Hypercarnivore & \multirow{3}{*}{ Hypercarnivore } \\
\hline Speothos venaticus (max) & 0.38899377 & Hypercarnivore & \\
\hline Canis lupus (max) & 0.39954606 & Hypercarnivore & \\
\hline Vulpes lagopus (max) & 0.40203548 & Mesocarnivore & \multirow{4}{*}{$\begin{array}{l}\text { Hypercarnivore / } \\
\text { Mesocarnivore }\end{array}$} \\
\hline Lycaon pictus (max) & 0.41193274 & Hypercarnivore & \\
\hline Lycalopex culpeus (max) & 0.41656346 & Mesocarnivore & \\
\hline Cuon alpinus (min) & 0.42707933 & Hypercarnivore & \\
\hline Lycalopex gymnocercus (max) & 0.43352668 & Omnivore & \multirow{8}{*}{$\begin{array}{c}\text { Hypercarnivore / } \\
\text { Mesocarnivore / } \\
\text { Omnivore }\end{array}$} \\
\hline Canis latrans (max) & 0.43876609 & Mesocarnivore & \\
\hline Lycaon pictus (min) & 0.4401231 & Hypercarnivore & \\
\hline Chrysocyon brachyurus (max) & 0.47260203 & Omnivore & \\
\hline Canis lupus (min) & 0.47866607 & Hypercarnivore & \\
\hline Canis aureus (max) & 0.48129375 & Mesocarnivore & \\
\hline Vulpes vulpes (max) & 0.48323788 & Mesocarnivore & \\
\hline Speothos venaticus (min) & 0.48422978 & Hypercarnivore & \\
\hline Canis latrans (min) & 0.48460054 & Mesocarnivore & \multirow{17}{*}{$\begin{array}{l}\text { Omnivore / } \\
\text { Mesocarnivore }\end{array}$} \\
\hline Lycalopex griseus (max) & 0.50013523 & Omnivore & \\
\hline Cerdocyon thous (max) & 0.50764504 & Omnivore & \\
\hline Vulpes lagopus (min) & 0.53516599 & Mesocarnivore & \\
\hline Urocyon cinereoargenteus (max) & 0.53516937 & Omnivore & \\
\hline Lycalopex culpeus (min) & 0.55065397 & Mesocarnivore & \\
\hline Chrysocyon brachyurus (min) & 0.55356594 & Omnivore & \\
\hline Vulpes vulpes (min) & 0.56869599 & Mesocarnivore & \\
\hline Vulpes zerda (max) & 0.59363335 & Omnivore & \\
\hline Vulpes zerda (min) & 0.5982215 & Omnivore & \\
\hline Lycalopex griseus (min) & 0.62284374 & Omnivore & \\
\hline Lycalopex gymnocercus (min) & 0.62465886 & Omnivore & \\
\hline Cerdocyon thous (min) & 0.65690314 & Omnivore & \\
\hline Lycalopex vetus (max) & 0.66255223 & Omnivore & \\
\hline Lycalopex vetus (min) & 0.69023133 & Omnivore & \\
\hline Urocyon cinereoargenteus (min) & 0.69226584 & Omnivore & \\
\hline Canis aureus (min) & 0.69539824 & Mesocarnivore & \\
\hline Otocyon megalotis (max) & 1.05831893 & Insectivore & \multirow{2}{*}{ Insectivore } \\
\hline Otocyon megalotis (min) & 1.12532476 & Insectivore & \\
\hline
\end{tabular}

\section{References}

Prevosti, F.J. 2006. [Grandes cánidos (Carnivora, Canidae) del Cuaternario de la República Argentina: sistemática, filogenia, bioestratigrafía y paleoecología. $\mathrm{PhD}$. Thesis, Universidad Nacional de La Plata, La Plata, 501 p. Unpublished.]. 